\title{
Field Notes on Social Media in Kenya
}

\author{
By \\ Kyalo NGUKU
}

A study submitted to the Faculty of Graduate and Postdoctoral Affairs in partial fulfilment of the degree of Master of Journalism at the School of Journalism and Communication, Carleton University.

\section{Carleton University}

Ottawa, Ontario

(C) Kyalo NGUKU 2015 


\section{ABSTRACT}

With the rapid adoption of mobile phones in Africa, social media has suddenly enabled ordinary citizens to engage political leaders and other public figures directly. This has led to tremendous change in public life. Public institutions are benefiting from the increased participation of ordinary Africans in the political and policy processes. However, social media has also led to some negative unintended consequences. Ethnicism and sectarianism are thriving as a result. Kenya has been a leader in the spread both of mobile phone and social media use in Africa. This is one important reason why it was chosen to gauge the impact of social media use on political participation in Africa. Kenya is a bellwether for trends in Africa.

The research in the summer of 2014 found evidence that social media indeed is empowering ordinary Kenyans to engage public figures and institutions more effectively and to shape the latter. The research found that those public figures and institutions that had adapted to the new digitised environment were influencing public discourse more effectively in their favour. It also found that a new class of Kenyans - the digital citizens - had greater influence with policymakers, and had an enhanced capacity to influence support or lack thereof for the latter at the grassroots. The research found that this influence could be positive as well as negative-in the sense that lies or hatemongering could easily spread from social networking sites to the village rumour mill. The study concluded that the widespread adoption of social media was more of a boon for the institutions of national life than a drawback, especially in a climate in which hard-worn media freedoms are being lost. 


\section{TABLE OF CONTENTS}

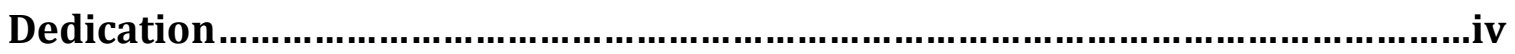

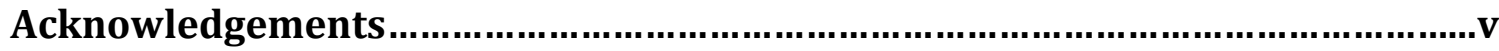

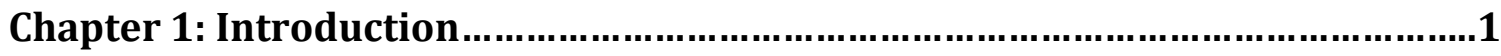

Chapter 2: Then: Analogue Times...................................................................

Chapter 3: Now: Digital Times................................................................20

Chapter 4: The Case of PeaceNet.....................................................................31

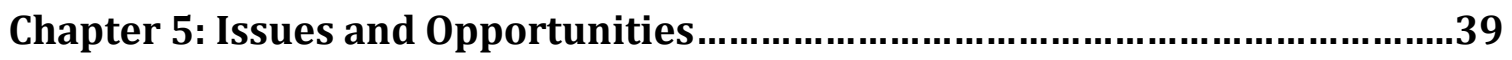

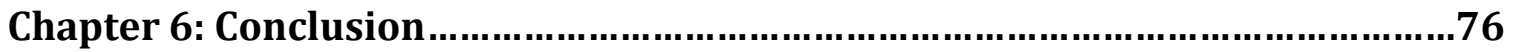

List of Primary Sources.......................................................................... 79

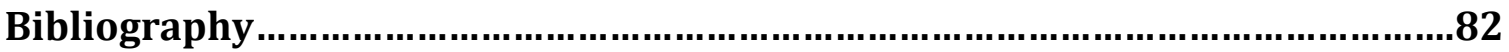




\section{DEDICATION}

I dedicate this study to my late father, Anthony Nguku ILUVE WAYA, who gave me my love of God, learning, and public service. My love of media and the outside world came from hanging around as my father played with the dial trying to pin down a stable signal on shortwave. I came to learn to look out for "saa sya ũvoo" (Kĩkamba: news time). 


\section{ACKNOWLEDGEMENTS}

It seems right and proper to start by thanking God for the opportunity to study at one of North America's finest journalism schools. God has a way of taking you where you really want to go even though at the time you may not realise what He is doing. I did not realise what a privilege it was to be accepted at Carleton until much later, when I learnt that I had somehow stumbled into the school that has led journalistic training and scholarship in the country since the beginning.

I would like to thank Mary Choueri, who returned that call when I sought to enquire in May about the possibility of joining in September 2013. I would like to thank her for following up and arranging to have the graduate supervisor to call me back. I would also like to thank her for patiently following through and walking with me to make sure that all the administrative details were ironed out.

I would like to thank Professor Susan Harada for acting swiftly to see that my somewhat belated application was processed in record time. The fact that my application was received and processed at the beginning of the summer holidays was not lost on me.

By the same token, as well as Professor Harada, I would like to thank Professor Chris Waddell and those others who sat on the selection committee for the great opportunity of studying at Canada's preeminent journalism school. I would also like to thank Professor Kirsten Kozolanka for taking the time to prepare us for the tough 
journey of putting together this sort of write-up. Professor Chris Dornan was also instrumental in making sure that I had sufficient funds to stay long enough in Kenya to complete my interviews, for which I thank him.

A special mention goes to my classmates and fellow stragglers, Noreen Fagan and Clive Emdon, who have been a source both of inspiration and encouragement.

Finally, I would like to thank Professor Waddell; my internal examiner, Professor Ira Wagman; and especially my supervisor, Professor Andrew Cohen, for making themselves available to guide my research project. I am especially grateful to Professor Cohen not just for bringing his wealth of experience and skill to bear, but also for his warmth, his enthusiasm, his faith in my ability, his encouragement, and the sincerity of his concern. 


\section{CHAPTER 1: INTRODUCTION}

This study demonstrates the perceived disproportionate and very real power that the Internet and social media have put in the hands of digital citizens. It shows the political engagement of a few million Kenyans who have access to a computer or mobile phone and are making their feelings known and affecting the way local politicians, civil society players, journalists, intergovernmental organisations, international personalities, and even foreign governments, conduct themselves within and in relation to Kenya. In particular, the piece aims to show how Kenyans' embrace of Internet and social media has affected the design of political communications aimed to rally public opinion behind competing visions of Kenyan public institutions.

Indeed there is a new player in the Kenyan and African political market: the digital citizen. Using social media and the blogosphere, the digital citizen has taken on actors as diverse as Kenyan media personality Caroline Mutoko, favourite son and US President Barack Obama, the UK's Foreign and Commonwealth Office, and CNN International, with telling effect. According to a Pew Research Center report published on 13 February 2014, Kenya is second only to South Africa in Africa south of the Sahara as far as mobile phone and smartphone ownership and Internet access are concerned. The report showed that once online Kenyans (76 per cent) were third in sub-Saharan Africa, marginally behind Ghanaians (77 per cent) and Nigerians (83 per cent) in terms of going on social networking sites. This year's Global Information Technology Report, published by the World Economic Forum in 
conjunction with France's INSEAD Business School and Cornell University, placed Kenya in sixth place in Africa in terms of "Internet-readiness". Of the five countries ranked higher - ie, Mauritius, Seychelles, South Africa, Rwanda and Cape Verdeonly South Africa ( $54 \mathrm{~m})$ had a population comparable to Kenya's $(46.7 \mathrm{~m})$.

Social media responses to local and international actors informed the reporting of the last general elections in Kenya. For instance, Facebook posters and tweeters on Twitter chastised Barack Obama for suggesting that media freedoms in the country were on a par with the dire situation in Syria. The UK and US governments, as well as the EU, had to fight public diplomacy wars in the social and legacy media against the perception that they were backing a certain presidential candidate. More recently, a well-known American preacher was forced to issue a public apology after Kenyan social media users took issue with what appeared to be an exaggeration of his humanitarian work in the country.

Using the hashtag \#SomeoneTellCNN, which on the eve of election day was the most trending topic on Twitter globally, Kenyans on Twitter (\#KOT) and other social networking sites rounded on CNN for reporting on an unnamed militia that supposedly was preparing for armed post-electoral conflict during the March 2013 general elections. The network was also forced to withdraw from its website a video report that gave the impression that the country was in the grip of election-related violence. It later apologized—on Twitter. On 13 August 2015, CNN again apologised to Kenya for mischaracterising the country as a "hotbed of terror". President Uhuru 
Kenyatta announced on his Facebook page that CNN Global Executive Vice-President and Managing Director Tony Maddox had called on him at State House, Nairobi and expressed "deep regret" over the slur repeatedly aired on the eve of Obama's visit to the country. Maddox's visit followed the suspension of a $100 \mathrm{~m}$-dollar annual advertising contract given to CNN by the Kenya Tourism Board.

These incidents have shaped the way that local and transnational news media outlets approach their work. As The Globe and Mail reporter Iain Marlow told a graduate journalism class at Carleton University on 18 November 2013 concerning his reporting from Ghana, the people an international reporter covers nowadays are likely themselves on Twitter, and will probably "call you out" if you misrepresent them. Social media users and bloggers have become "public watchmen", to use the favoured Kenyan term. However, they have also been accused of malpractice such as hate speech. Influential US-based Kenyan academic, human rights campaigner and columnist Makau Mutua recently became the target on Twitter of hate mongers that he has branded "bloviators".

In this study, carried out during a visit to Kenya in the summer of 2014, I research and reflect on the challenges and opportunities presented by social media in Kenya's public life. My research sheds some light on the consequences of citizen journalism and social media for the development of economic, political and social institutions in democratizing societies such as Kenya, as well as the implications for traditional news media. I pay particular attention to the way political actors-local and foreign, 
organizations and individuals-are having to adapt their political strategies as the Internet and social media become more important in Kenyan public life.

This study, produced as part of my Master of Journalism degree, assesses the impact of social media on the political and policy processes in Kenya and examines the way that political actors are adapting their political strategies to the growing influence of digital citizens. At the end of the research, considering the potential "dispersal of power" afforded to many by the Internet and the resultant conversion of journalists from gatekeepers to "gatewatchers" (Hellmueller et al, 2013), I answer the following question: could the growing influence of social media on the way that new ideas are marketed in Kenya portend a more influential role for the digital citizen in the shaping of public institutions in democratising countries? In particular, I examine the way that various actors have previously tackled the problem of corruption and impunity in public life and its effect on public institutions, and the way they are dealing with it now that social media is in the ascendancy.

African countries suddenly find themselves among the world's fastest growing economies. This year's International Monetary Fund (IMF) figures show that Kenya (6.9 per cent) is the world's $16^{\text {th }}$ fastest growing economy. Kenya's economy is Africa's eighth fastest growing. Estimates of its 2015 GDP per capita based on current prices stands at USD 1,588 (CAD 2,079). Western Europe once powered the global economy for better or for worse. North America, and Japan, then took over in what came to be known in some quarters as the "American Century". Currently, 
robust economic growth in the likes of Brazil, India and China is driving the global economy. Africa is widely tipped to become the next major engine of global economic growth in an increasingly interconnected world.

This global interconnectedness means that the economic, political and social institutions that shape African interactions with other economies will affect the fortunes of the latter. This also means that both local and international actors in the Kenyan market have greater stakes than ever before in the direction that institutional reforms take. Major geopolitical players, for instance, are no longer merely vying for the role of ideological tutor to a recently created country, as was the case during the Cold War. They are now competing for economically significant political influence in a market that is on the cusp of becoming globally consequential.

Kenya, Africa's seventh largest economy according to the IMF, is the preferred Africa staging post for an increasing number of multinationals, global non-profit organisations and intergovernmental organisations. Upwards of 60 international organisations and transnational corporations have their Africa regional offices in Nairobi, a second-tier global city according to the Globalization and World Cities Research Network based at the UK's Loughborough University. These organisations include IBM, Google, Diageo, Cisco Systems, Qualcomm, BlackBerry, Sony, Asus, General Electric, Eltek, Huawei, LG, the BBC, CNN, China Central TV, Xinhua News Agency, Visa Inc, Mastercard, Pfizer, the World Bank, the IMF, the International Civil 
Aviation Organisation, and Amnesty International. The country's proposed purposebuilt tech city, dubbed the "Silicon Savannah", is expected to become one of the continent's foremost centres for technological innovation. Kenya hosts one of only four major UN multiagency office sites-the others being in New York, Geneva, and Vienna. This is the only such UN office complex in the developing world. The Indian Ocean port of Mombasa services not just Kenya, but also Uganda, Burundi, Rwanda, South Sudan and the eastern DRCongo. Kenya is the sub-region's financial and manufacturing centre. This year, the country became the second African country to host the Global Entrepreneurship Summit after Morocco.

Kenya is a major bulwark against global terrorism. It is a leading frontline state in the fight against terrorism in the Horn of Africa. The country is a key source of stability in a sub-region wracked by civil strife, and a regional arbiter in many of those conflicts. Kenya heads an African Union panel tasked to lobby internationally for permanent African seats at the UN Security Council. The country is one of a handful of fairly stable democracies in the continent.

Because of highly significant educational reforms in Kenya over the last decade, coupled with the fact that Africa has seen the world's fastest rate of digitisation in recent times, global and local actors-ie, public figures, corporations, institutions and governments-are competing to influence the character and shape of Kenya's public institutions largely by wooing one of Africa's most politically engaged and technologically savvy populations. The March 2013 general elections broke popular 
participation records locally, regionally and globally. Participation rates averaged 85.91 per cent. Using the Internet and social media, Kenyans suddenly have ways of making their feelings known and influencing public debate without the overt help of legacy media. Institutional and individual political actors can bypass legacy media and connect with their audiences. Geopolitically speaking, the Brazilians, the Russians, the Indians and especially the Chinese have joined the fray, meaning that the country has alternatives to Western economic and political partnerships.

At the same time, the influence of market economics and globalisation on the country has only grown.

All this means that the actors involved must contend with the need to sell their economic and political policies to a more informed public in a context in which millions can go online and cause a lot of trouble for media personalities, local and global political figures, political parties, and even foreign governments. For better and for worse, the Kenyan political market is rapidly maturing (some may say degenerating), and social media has become an unavoidable marketing site.

This study will seek to provide a sense of what the rapid changes in Kenyan political communications presage for the future. It will show what worked before and is not working now. It will seek to establish what trends are peculiar to Kenya and which are universal. In particular, it tries to shed light on the significant emerging adaptive strategies adopted by institutional and governmental players vis-à-vis development 
communication (loosely defined as the use of communication to facilitate the development of public institutions) in an increasingly competitive marketplace of ideas complicated by the participation of digital citizens.

This piece relies on primary sources on the ground. I travelled to Kenya to speak to relevant sources-in the media, in the non-profit sector, and in academia. Because of concerns about my security-it appeared to me that my telecommunications was being monitored-I decided not to pursue my initial plans to talk to politicians and political activists who, nevertheless, have been discussed in the following chapters. I also read widely to give context to the interviews.

I read extensively on public diplomacy, political marketing, development communications and social media in Kenya. This helped to explain the links between these four interrelated areas of endeavour. It also allowed me to locate my research and contribution to this body of knowledge within the context of current debate in Kenya.

The research confirmed some of my suspicions. But there were also some surprises. In some ways, the impact of social media mirrors what one would expect anywhere. But in other ways, the country's level of development meant that the introduction of social media had thrown up some peculiar situations. 


\section{CHAPTER 2: THEN: ANALOGUE TIMES}

The story of the mass media in contemporary Kenya coincides with the coming of the British imperialists. In 1902, the then East African Standard was established. At the time, Kenya did not exist as a colony: there was just the British East African Protectorate (ie, today's Kenya and Uganda), hence the name of the newspaper. The English-language daily served the settler European population at first. Over the decades, its content, public, ownership and, ultimately, name, changed. Today, the newspaper is locally owned (former President Daniel arap Moi is believed to have the controlling stake) and is the flagship of a group that includes the Kenya Television Network (KTN), the country's first privately owned TV station, and a handful of radio stations. In 1953, the African Broadcasting Corporation was established. The station offered broadcasting in Swahili, Arabic, Kikuyu, Dholuo, and Kikamba. The following year, the colonial government established the Kenya Broadcasting Corporation (KBC). In 1961, the KBC opened Sauti ya Mvita (Swahili: the Voice of Mvita) and Lake Station, respectively in the coastal and lakeside cities of Mombasa and Kisumu.

The KBC was nationalised in 1964; after independence, it was renamed the Voice of Kenya (VOK). The VOK dominated national conversations until around 1990, when the collapse of Soviet communism led to a groundswell of democratic change across Africa and elsewhere in the world. Suddenly there was a proliferation of independent media outlets. 
In 1958, the Aga Khan founded the Swahili-language Taifa Leo (Swahili for the Daily Nation). The following year, he founded the English-language Daily Nation. The Nation (later the Nation Media Group) would slowly grow into east and central Africa's largest and most influential media group, adding radio and TV outlets and expanding into Uganda and Tanzania in the heady days after the fall of the Berlin Wall.

In 1989, KTN became the country's first privately owned TV station. In 1996, Capital FM became the country's first privately owned radio station.

From independence in 1963 to 1989 when the Berlin wall fell and Kenya ceased to be a buffer against communism in the region, the media primarily served to chronicle events in public life, to carry the message of the government of the day, and to entertain. In this respect, the young nation had merely carried over the media culture inherited from the colonial state. The media, whether publicly or privately owned, served as the informational extension of government or its propaganda tool. The KBC, which would miraculously recover its original name upon the return of multipartyism in the 1990s, had served as a mouthpiece for the colonial government during the extended war on freedom fighters known as the Emergency, in the 1950s. During this time, the future rulers of a nascent Kenya clearly learned a thing or two about the importance of media. Media served not just as a way of disseminating information and projecting political and military power, it also served to legitimise and set in stone the decisions of the ruling class in the national psyche. 
The authority of the printed word and that voice coming out of the little transistor radio made the message of power an article of faith. The media had often proved to be more powerful than the gun in the hands of the colonial authorities; so also it would in the hands of the country's postcolonial elites.

At independence, the newly renamed VOK inherited broadcast services in several languages and a countrywide infrastructure. The government had a monopoly of broadcast media as well as virtual control over the print media-partly through an authoritarian style of government underpinned by Cold War alliances and expediency, but also through a straightforward financial hold owing to the government being the single largest advertiser in the media market. In later years, it would help the political elite that the Aga Khan would enter into business with influential elements in the ruling class; the historic Standard Media Group would slowly fall into the hands of local businessmen with strong ties to the presidency; and the Kenya African National Union (Kanu), the independence party, would begin its own paper in 1983: the then-influential Kenya Times. The Kenya Times, which would briefly overtake The Standard as the country's second largest newspaper after the Daily Nation, had a Swahili-language sister publication: Kenya Leo.

The years after independence in the 1960s were briefly characterised by a measure of political pluralism. Prime Minister Jomo Kenyatta's Kanu had convinced its main rival, Ronald Ngala's Kenya African Democratic Union (Kadu), to give up its autonomy and dissolve into Kanu. This happened. Dissent thereafter would only be 
possible within Kanu and, by extension, the cabinet. In 1966, socialist-leaning VicePresident Jaramogi Oginga Odinga, then the country's second most important political figure after Kenyatta, formed the Kenya People's Union (KPU) after falling out with Kenyatta. This reintroduced multipartyism, but only briefly. Kenyatta soon banned the KPU and jailed his rival. In 1969, Kanu was again the de facto sole party in the country. This continued until 1982 when, after a failed coup, the constitution was changed to make Kanu the de jure sole party in the country.

After independence in 1963, a lot of leading left-leaning politicians were sidelined. Others died quite conveniently, often in highly suspicious circumstances. As the political architecture quickly turned into a monolith with the tacit and sometimes overt support of benefactors in the West, the stifling of dissent went from being a witch-hunt against leftists, to housecleaning within the ruling party and the government apparatus. The methods were refined to the following: intimidation, clientelism, patronage, political isolation, exclusion from the one-party system, character assassination, impoverishment, torture, imprisonment, and, when all else failed, a conveniently fatal road accident or physical disappearance. The statecontrolled media served as an extension of the official propaganda apparatus, deifying the president (the president had to make the headlines practically at every hourly news bulletin); demonising dissenting voices; setting the tone for officially sanctioned national conversations; explaining away disappearances and deaths; proclaiming presidential fiats; and, by the same token, announcing presidential appointments and firings. There was also a measure of entertainment. There was 
very little entertainment variety in those days-especially if, like the overwhelming majority of Kenyans, you lived in the countryside.

Political messaging under the authoritarian rule of the Cold War years was straightforward: outlets, including private media, said what the government wanted said. News was not news unless it magnified government luminaries and their pet projects. Using media outlets, the state turned the voices of dissent into "subversives" and pariahs. A lot of leaders were ruined financially, jailed, maimed, or simply made to disappear. For as long as the Soviet Union threatened to expand its influence across the region, the Kenyatta-Kanu (and thereafter Moi-Kanu) regime could count on unstinting Western support.

In those days independent-minded reporters did not do very well. But some still did try to bring an alternative perspective to bear on things. One such journalist was Phillip Ochieng, who somehow was able to remain independent as the Editor-inChief of the Kenya Times, the newspaper owned by the party of government. Eventually, he was sacked.

In the midst of all these restrictions, the Weekly Review magazine, a miracle of political journalism, still managed to take root in 1975 and flourish in the years after independence. Harvard-educated nuclear physicist Hilary Ng'weno, the Daily Nation's first indigenous Editor-in-Chief, at first established Joe, a political satire comic magazine, in the years immediately after independence. But it was the Weekly 
Review magazine that came to establish Kenyan journalism as some of the finest on the continent. Many of Kenya's best-loved journalists would cut their teeth at the Weekly Review, a publication that somehow managed to offer information and highly entertaining depictions of the shenanigans and intrigues of a corrupt political class without attracting dangerous attention from State House, the seat of real political and economic power. The Weekly Review closed in 1999, shortly after the liberalisation of the media in Kenya. Ngw'eno wanted to retire but just would not entrust his baby to anyone else.

During the years of one-party rule, popular political participation was not actually encouraged-except to applaud the president and his entourage. Elections invariably brought those favoured by the president and party apparatchik into power. You did not ask questions as a citizen; you thought what you were told to think. Kanu came to be known as "baba na mama" (Swahili for father and mother). It was the party of "wapende wasipende" (Swahili: whether they like it or not). As one politician once said infamously, the only vote you needed was that of the president. Everyone else's was irrelevant or, at best, ceremonial. That is how my favourite uncle and mentor lost his job as the Member of Parliament (MP) for our constituency. An aspiring second-term MP, he had won the party nomination. But he was just too independent and honest for party headquarters. So they arranged for a rerun and parachuted in an opposition candidate who was causing too much grief in the years after the return of multipartyism for the liking of party headquarters (the 
actual expression in Swahili was "lowered down in a basket"). My uncle did not run again.

The "analogue" years-to use the term currently in fashion in Kenya-coincided with institutional development and a political process in the image of its patrons. In Kenya, analogue has come to mean old and démodé, a metonymy for the time before digitisation. Radio was king (the majority of the people could neither read nor afford TV sets even if they lived within range). Locally, radio was firmly in the control of a small political elite who discouraged genuine popular participation in the political process. Political messaging was designed to promote personality cults and to discourage dissent. Political careers depended on kowtowing to the "big man" in Nairobi and his courtiers.

In the Kenyatta years, there was a genuine attempt to make the lives of the people better and to build public institutions that worked. Amidst the oligarchical corruption, the ethnicism and the fear, many highly qualified men and women worked to shape fairly credible public institutions. Barack Obama Snr, whose extensive and lasting contributions to Kenya's public infrastructure and tourism sector are only now being credited publicly, comes to mind. The nation-building project benefited from the work of these professionals as it also did from the influence of a shared national educational curriculum and radio. Those in power may have abused radio. Still, it did give a nascent nation created from a mishmash of unacknowledged pre-colonial nation states a communal consciousness. 
From the armed forces by way of the courts to the police to parliament, Kenyans came to understand that to be sure of getting any kind of public service, you either needed "to know somebody" personally or to pay "something small" ("toa kitu kidogo" in Swahili). Corruption became key to the way that public institutions were developed. As one high-profile corruption suspect once reportedly said memorably, "Why hire a lawyer if you can buy a judge?"

At a time when dissent had been criminalised and police torture and extrajudicial executions were common, it became very hard to get information about what was really going on in the country or even what its people could reasonably aspire to. The sole media outlet with national reach had been turned into a mouthpiece of the state. Indeed the British Broadcasting Corporation (BBC) was always careful to call such media outlets "state broadcasters" as opposed to "public service broadcasters". In order to have any idea of what might be going on in their own country, the people turned to foreign media outlets broadcasting on shortwave (SW) radio.

There were a lot of foreign outlets that maintained radio broadcast services into Kenya and other parts of Africa. These included Radio Canada International, Radio Moscow, China Radio International (CRI), Radio Japan, Radio Netherlands International, Deustche Welle, Radio France International (RFI), the Voice of America (VOA), and the BBC. Children across the nation learned that the news bulletin on the hour was something of a sacred moment. They kept quiet and 
listened or went outside to play. Like every other Kenyan who cared to know what was going on, I came to learn that the foreign radio broadcasts were a more reliable source of news than the VOK.

In those days foreign radio journalists became household names across the continent. For instance, when the BBC's Chris Binkerton died in May 2002, he was mourned across Africa. Binkerton had become the voice of the BBC's highly influential "Focus on Africa" programme for decades.

Radio was the principal means through which the Cold War protagonists exercised public diplomacy in Kenya and elsewhere in Africa. Compared to other means of public diplomacy—foreign aid, famine relief, scholarship bursaries, etc-radio clearly gave a greater return on investment. It was also something that could be cheaply kept up. Foreign governments could tell Kenyans what to think about Cold War enemies. They could extoll the virtues of whatever ideological systemwhether communist, capitalist, or socialist. VOA and Radio Moscow tended to be more direct in their propagandist messaging. For instance, every VOA news bulletin, whether in English or in Swahili, would be followed by an editorial clearly signposted as "the official policy position of the Government of the United States of America".

When Communism collapsed, western governments and institutions nolonger needed to uphold authoritarian rule in Kenya and elsewhere in the continent. 
Suddenly those fighting for freedom and greater popular participation in government had the support of western institutions, foremost of which media outlets. The number of opposition voices being heard in Kenyan homes grew exponentially as foreign broadcasters opened up the airwaves to dissenting voices. Hitherto little-known or demonised personalities such as eventual Nobel laureate Wangari Maathai suddenly became very influential. Long-time opposition leader Raila Odinga, who had suffered torture as a political prisoner and like his father, Jaramogi Oginga Odinga, had been locked out of the political system, suddenly found his public voice. Indeed his father, affectionately known in the country as "the doyen of opposition politics", nearly won the first multiparty elections held in the country in 1992 alongside yet another former political prisoner, Kenneth Matiba.

The fall of Communism, the end of one-party rule and the opening up of the media space to private investors coincided with the advent of FM radio at the beginning of the 1990s. After Capital FM became the first privately owned radio station in the country, the country soon became awash with both locally and foreign owned FM radio stations. Issuing broadcast licenses became a highly political affair. It became yet another battlefield for opening up politics to genuine popular participation. When Moi became the first and so far only sitting Kenyan president ever to call-in live on a popular political talk show on the opposition-leaning Nation FM, the entire country understood that this would be a defining moment. The man who became locally synonymous with the expression "imperial presidency" was being called to account and was actually responding publicly! 
The proliferation of local FM radio stations across the country was accompanied by the advent of foreign broadcasters such as the BBC, VOA, CRI, and RFI establishing FM relay stations locally. Soon many of them would also establish local studios. The print media also proliferated despite repeated legislative and legal attempts to slow it down. The country began to have its first independent radio and TV stars. The talk shows became an unavoidable stop for politicians looking to rally the people behind their electoral platforms and policies.

Two more changes would take place in the country at around the same time to usher in the "digital" times: the advent of Internet and mobile telephony. Africa Online became the country's first Internet service provider (ISP) in 1994. Safaricom became the first mobile telephone carrier in 1997. 


\section{CHAPTER 3: NOW: DIGITAL TIMES}

It was the 2013 presidential ticket of Uhuru Kenyatta and William Ruto that branded the national psyche with the notion of a "digital" generation. The highly scripted Jubilee Alliance campaign, which made much of the age gap between its ticket and the rival Cord (Coalition for Reforms and Democracy) ticket of Raila Odinga and Kalonzo Musyoka, was the first to bring in Western-style electoral campaign professionals to Kenya. Ironically the pollsters were British. The two men on the ticket were fighting Western-led attempts to disqualify them as candidates over suspicions of crimes against humanity in the post-election violence of 2008.

Veteran media analyst Rashid Abdi, who has since returned to the International Crisis Group (ICG), said during our interview: "For this government, social media is an intrinsic part of their corporate identity. The government claims to be 'digital'. Egovernment is being pushed. There has been a lot of investment in its infrastructure. It is a matter of identity for this government."

Luis G Franceschi, a specialist of international and constitutional law, is the founding dean of the Strathmore Law School in Nairobi and a columnist with the Daily Nation, the country's largest daily newspaper. He echoes Abdi. He told me that the country's major political players—the president and his deputy especially—do pay close attention to conversations on social media. He said: "The government gives importance-Uhuru and Ruto give importance to whatever is trending on social media. I think that their advisors keep an eye on what is happening on social media 
because in a way when it comes to, not lobbyists, but lobbying power, people who are on social media have a greater reach (in policymaking circles)."

Samuel Kamau teaches at the University of Nairobi's School of Journalism. He is also its "online champion", heading a team of four that works to boost the school's online visibility. Kamau's doctoral thesis, "The Influence of Social Networking Sites on Political Attitudes and Behaviour Among the Urban Youth in Kenya," looks at the growing influence of social media on the behaviour of political actors and pubic institutions in Kenya.

"By the time I did my study, we only had about 3.6m Kenyans on Facebook at that particular point," he says. "That was last year around November (2013). That is about 8 per cent of the Kenyan population. It is significant because you might find that the people on social media are opinion leaders because you find journalists, you will find some scholars, you will find public figures-these are people with influence. So the 8 per cent of the Kenyan population-it may be small but it could be significant."

Kamau explains why the victors of the 2013 presidential elections have invested so much in their online presence. "Social media crystallize opinion around something, and that is where the opinion shapers play their role," he says. "They will say something and then you will see debate... So you can't ignore that. You must have a strategy, you must respond. You must guide the conversation. And I think that is 
what Uhuru Kenyatta did quite well, by bringing on board certain people who are constantly and actively updating information." He says that Kenyatta had a strategy whose role was to provide information on social media with a view to guiding conversations, adding: "If you leave it (social media) and decide that it is not a platform you will use, people will be there. They will end up defining you on the platform... That makes (Kenyatta's) Jubilee very strong on social media. Because Cord has a few people who try to do that, but it is not as organised as these guys."

Simon Ochola, a senior political reporter with the KBC, wrote a senior thesis entitled, "How Government Uses Social Media to Disseminate Policies Across the Country in the Wake of Devolution." His thesis looks at the impact of social media as a tool for expanding popular participation in the policy process.

Ochola says that his choice of subject was inspired by a requirement in the new constitution promulgated in 2010 that ordinary Kenyan citizens should be enabled to take part in the policy process. "I was looking at it this way," he says, "given the fact that the demography in this country is basically that... the youth are actually many in this country-and we all know that most of them are actually owning a phone or two and those phones actually can access Internet-how well then the central government and of course the devolved (county) governments would use social media to actually ensure that Kenyans can participate in policy formulation as enshrined in the constitution." 
Ochola found out that in most major towns, people are using the Internet a lot and that they are contributing their opinions on "very many" government policies on the Internet. "It also came out very strong that most government institutions and especially departments-the security department, the cultural department, and the Office of the President-are constantly using social media to actually update on what they are doing and the policies and the programmes that are coming up, that they are likely to implement in the future," he says. His study revealed that a lot of leaders had taken to social media. He notes: "This government actually came on a platform of a digital government-many leaders are actually trying as much as they can to subscribe on the social media so that they can actually disseminate information on social media."

With the fall of the Moi-Kanu regime after the 2002 multiparty elections, the opening up of the democratic space that had been going on for a little over a decade appeared to have been consolidated. Whereas it had already become acceptable to openly criticise and even poke fun at the sacred cows in the kraals of power in the preceding decade (the Redikyulass comedy trio became something of a national institution, satirising Moi and his successor Mwai Kibaki as well as Moi's sidekick, Joseph Kamotho), Kibaki's accession to power ushered in an unprecedented period of media and popular freedom. Kibaki's laidback style became the source of much mirth. Then-opposition leader and future political ally Kenyatta memorably described Kibaki's style as "hands-off, eyes-off, everything-off". However, it was 
generally acknowledged that the Kibaki years led to many overdue changes in every aspect of national life.

Kibaki's National Rainbow Coalition (Narc) government oversaw the reconstruction and expansion of public infrastructure that had been increasingly neglected during the Moi years. Efforts began to expand the national power grid to bring in the rural masses. New energy contracts were signed to increase the supply of power. The people were allowed to say whatever they pleased. And telecommunications and media outlets grew at an unprecedented rate. By the time Kibaki's second term ended in 2012, there were up to 13.8 million Internet users and 30.7 million mobile phone lines in the country. Kibaki and coalition co-principal Odinga would present the country with yet another watershed moment: the 2008 post-election violence.

The Kibaki years came after 10 years during which Moi had clung to power for two five-year terms after the restoration of multipartyism, arguing that the new twoterm limit could not be applied retroactively. As we have seen, this period-the 1990s essentially-was characterised by incremental gains in freedom of speech. The government continued to try to slow things down-for instance by making it mandatory for any new media outlet to post a $1 \mathrm{~m}$-shilling (10,000-dollar) bond before they could be allowed to publish or go on air. But the people and the oppositionists had tasted freedom and were not about to give it up. By the time Kibaki's coalition took power, defeating Moi's handpicked successor Uhuru Kenyatta, it was perfectly normal and expected to criticise public figures and 
institutions. The trend picked up with the advent of the Internet and mobile telephony.

Initially social media-and mobile telephony came to equate social media in the Kenyan context—was seen as a place where people could exchange a bit of "banter", according to Douglas Gichuki, reader in intellectual property and technology law at the Strathmore Law School. Kenyans took to social media like fish to water. It became common to trade jokes on social media. According to Mathias Muindi, a media analyst for the BBC's monitoring service (BBC Monitoring), "Kenyans see mobile phones as devices for texting—not calling." It became common to create and forward all manner of jokes by text. The years of innocence would end with the fallout from the contentious presidential elections of December 2007, when a rift within the hitherto ruling coalition would be compounded by claims that Kibaki had rigged the elections. Former ally and chief election rival Odinga refused to accept the results. What followed was a period of protracted conflict. Suddenly social media—and especially mass texting—had become more than just the means for harmless banter.

"Kenya is a highly fragmented society," says Abdi. "Social media has served to exacerbate that fragmentation." Abdi says that whereas radio served to bring the country together, social media has served to do the exact opposite. As he put it, "Radio has affected Kenyan culture (positively). On the other hand, social media has 
been affected by Kenyan culture (negatively)." He says that social media has fallen prey to "hate messaging".

P Ogoda, who is a lecturer in political science at the University of Nairobi, is scandalised by the extent of hatemongering in Kenya's social media. She says: "We are a divided nation, and if you want to prove it, go and see what people are talking about on Facebook. Sordid stuff! We talk about we are going to filter it. Nothing like that! I mean, because it is very divisive. I mean, I told my friend that I refuse to check on anything to do with Facebook, Twitter, or WhatsApp because, I mean, the kind of stuff that is going on and is being exchanged on there! And I don't want to waste my time and take my time to read it."

Says Kamau: “There was an article the other day, I can't remember by who, that said that if you want to know how a country burns, check social media... It is very effective for hate speech and dividing opinion."

But Gichuki takes a more benign view of things. "What is happening on social media has been going (on) for a long time," he says. "It is just now manifest on social media. My personal take on it is that it will blow-it is a head of steam. That is a conversation that needs to be had, stupidity that needs to be aired until there iswe get to the point of boredom where we then ask, okay, be that as it may, the country must move forward." 
Gichuki feels that the process through which the country's peoples are going to become one nation must pass through conversations that will include stereotyping, "with some people referring to the genitalia of others, some people referring to the thieving habits of others" (respectively, the ethnic Luo of Odinga, who do not traditionally circumcise their men, and the ethnic Kikuyu of Kenyatta, who are supposed to love money to excess). He refers to this as "a necessary conversation" for Kenya to become a nation state. "Becoming a nation is a thing of time, is a thing of accident, is a thing of purpose," he says. "But you cannot hurry it, you see." Gichuki points to the national community-forming process in other countries, highlighting Germany and the UK in particular as proof that "you cannot compel the sense of becoming a nation". He says that the attitudes of the people need a while to catch up with what the constitution declares: that Kenya is a nation. "Kenya's law is ahead of the attitudes of Kenyans," he says, "which is the idea that I am truly a Luo, but I am also truly a Kenyan. There is no rivalry between those two things."

Gichuki refers to the oftentimes-unsettling exchanges on social media as "that playacting of a yet immature nation". He says that even though echoes of the stereotyping may yet be there in a century, there will be a bigger discussion about equality and inequality. He says that the online debates nolonger annoy him but, rather, amuse him. The excessive generalisation does not worry him because "Kenyans have enough of a sense of humour to ride the negativity of those stereotypes". 
Indeed social media and mass texting became a favourite means for organising post2008. Rumours flew in every direction. Incitement became commonplace. At a time of unparalleled civil strife in the country's post-colonial history, social media came of age both as a force for good and a force for evil.

In later years mobile telephone carriers would filter out hate speech. Social media would be monitored by the government, thus encouraging a measure of selfcensorship. But at the time immediately after the post-election violence, the country fell victim to the same freedoms that it had fought so had to reclaim from the political elite and which it had come to take for granted. The ethnic cleansing and retaliatory killings that put the country on the brink of civil war was fuelled as much by legacy media as it was by social media. It was easy to identify radio stations such as the Kalenjin-language Kass FM, now synonymous with crimes-against-humanity cases at The Hague. But bulk texting, which was used by Kenyans in the same way as social media at the time, did just as much harm if not more, according to Muindi, Ogoda and others. It can be argued that it is a mercy the fact that M-Pesa, the mobile phone cash transfer system invented in Kenya, was still only in its infancy. An easier facility for moving money around would have facilitated the mobilisation of the killing gangs with disastrous ease.

But just as social media and texting became tools in the hands of the more dangerous elements, they also became tools in the hands of the good guys, so to 
speak. Ogoda says that she witnessed first-hand how gangs of would-be killers would be given away way before they arrived at their target destination. She says of the post-election violence of 2008: "That was for me the point at which I said, Wow, this thing has an effect. Look at its facilitation of the statement 'global village'. Somebody is in (rural) Sirare, Terime and they know the number of Citi Hoppa's (buses belonging to a Nairobi-based mass transit company) carrying who with which ammunition, and people get ready and waited for them in Uyugis. There were murders and Citi Hoppa's burned. Another one burned in Homa Bay, another one in Migori, another one in Sori. (All locations in western Kenya.) People already knew that they were coming so were already waiting. So, you know, that kind of impact. So whereas whoever was sending them hoped for a surprise attack, people already knew they were coming so were already waiting."

Gichuki says that many non-governmental organisations (NGOs) turned social media and mobile telephones into an invaluable resource in the wake of the disputed elections. He singles out the Red Cross, saying that its reports on casualties and other developments were so uncompromisingly accurate that legacy media and other public institutions found themselves fearing to be called out. In the course of the 2008 post-election violence, members of the public used a crowd-sourced platform called Ushahidi (Swahili: evidence/testimony) to report incidents during the post-election violence. Ushahidi, which is now being used internationally, worked as a large number of texts from a given part of the country pointed to a hotspot needing immediate response by creating a cluster on the computer 
monitors. Ushahidi was used during the violence to direct police, the Red Cross and other emergency responders to the hotspots. As Gichuki notes, Ushahidi provided another dividend: "Of course the beauty of such applications as Ushahidi is that then formal media, which can be put under a lot of pressure by the police, by politicians, is not-then has to answer and say, why does the Ushahidi platform say there are 50 deaths and you say there are two? Why do these pictures show 50 men dead and you say that three died?"

Ochola says that the Kenya Red Cross's social media presence during the postelection crisis established its public profile as a credible institution. He says that the Red Cross initially had not enjoyed much visibility with the public. However, its use of social media had made it more "popular" with the public. "Today we actually use social media to get facts from whether there has been an accident somewhere or a rapid response mechanism by Red Cross," he says, "and we actually do stories based on posts on their site, because they are actually credible if anything is coming from them." 


\section{CHAPTER 4: THE CASE OF PEACENET}

NGOs saw an opportunity in social media. Social media could be used to prevent violence by setting up early-warning systems, among other things. PeaceNet, in particular, played a central role in coordinating the work of a large number of NGOs and grassroots community organisers. The work of this consortium centred on a series of specialist online platforms and toll-free telephone numbers that served different purposes. Ushahidi would become one of their brainchildren.

Founded in 1993 as the Ethnic Clashes Network (ECN), the organisation would change its name to Peace and Development Network (PeaceNet) in 1995 after broadening its mandate. In 2005, the NGO changed its legal status to that of a trust. As the name suggests, ECN was the unintended product of the ethnic clashes of the 1992 general elections, as the Moi-Kanu regime fought to stay in power in the face of a groundswell of unpopularity. In keeping with a pattern that had been going on every electoral cycle, many Kenyans were displaced in tribal clashes that happened mainly in the multi-ethnic Rift Valley Province (west-central Kenya) and on the coast, in conflicts widely blamed on the ruling party Kanu and on officials within the provincial administration accused of rigging the elections. Displaced people could not vote, so the prevailing rigging wisdom went. And so it was. This was seen as a way for the ruling party to discourage popular participation in the political process, in particular among the numerous ethnic Kikuyu. The Kikuyu tended to support the opposition at the time. 
The organisation, formed by a consortium initially consisting of Oxfam Great Britain, the Mennonite Central Committee and the Anglican Desk, initially sought to pick up the pieces after the killing, maiming and displacement of vast numbers of people, ostensibly on the basis of their ethnicity and in pursuit of the land that they occupied. Indeed the consortium's website acknowledges what became common knowledge at the time: its mission was to come to the aid of "the victims of politically motivated ethnic violence". When its mandate broadened in 1995, its preoccupation remained how the symptoms of political dysfunction might be dealt with. Its principal concern became to broaden popular participation in the political process. It began to enlist the help of ordinary people in working for lasting peace and security.

PeaceNet became known as PeaceNet-Kenya because of its international affiliation with similar organisations within the Association of Progressive Communications (APC). Founded in 1990, the international umbrella body's website says the following about its mission:

“APC's mission is to empower and support organisations, social movements and individuals in and through the use of information and communication technologies (ICTs) to build strategic communities and initiatives for the purpose of making meaningful contributions to equitable human development, social justice, participatory political processes and environmental sustainability." 
The organisation, which comprises a vast number of affiliates around the world and whose causes are equally diverse, refers to itself as being both "an organisation and a network".

PeaceNet-Kenya works the same way. According to Olga Mutoro, its Programme Officer for Policy and Governance and Acting Programme Manager, the organisation has different partnerships for different causes. Mutoro admits that "the big NGOs mainly use legacy media" but adds: "Nowadays you can't do without social media. To some level social media does give those who use them added say. Whatever is trending (on social media) tends to get the attention of most people. We use social media to reach out to many people, especially young people. It is an important part of our work. But then again, as peace builders, it is a major concern-an emerging issue-one of the major dynamics that we have to face." This concern, according to Mutoro and many others, has to do with the ease with which social media has been used to divide the people along ethnic and sectarian lines.

Since its formation, PeaceNet has become a leader in coordinating popular participation in ways that have affected public life and institutions. Besides the original founding NGOs, the network has gone on to include international, national, and regional partners. These include ActionAid, Global Communities, Saferworld, USAID, the Norwegian Refugee Council, Care International, and the International Rescue Committee (international); Kituo cha Sheria (Swahili: Centre for Law), the 
African Youth Trust, the Nairobi Peace Initiative, Accord, The Youth Banner, and Usalama (Swahili: security—national).

PeaceNet has also been partnering with the government in more recent times-in the shape of the now-defunct Ministry of Justice and, most recently, the National Cohesion and Integration Commission (NCIC). The latter's primary mission is to combat the political exploitation of ethnicism.

Says Mutoro: "We have partners who come in for specific programmes. We have partners who come in to build new capacity. We have different partners for our advocacy work who come in at different levels-regional, national, international, some even very local. We have different structures based on the need. Some are ad hoc. It depends on the expertise, resources, and commitment that the partners are bringing on board. We have partnerships based on a framework of engagementMOUs, contracts and even others without contracts."

PeaceNet is active in legislative lobbying and advocacy. Its website says: "The lobbying and advocacy subset of the programme is primarily responsible for mobilizing various forces of peace to ensure that appropriate legislation, policies and programs are developed at the national and local levels to promote a sustainable culture of peace in Kenya." 
Mutoro says that PeaceNet also uses old-fashioned "analogue" lobbying and advocacy methods. "We form networks and then work to influence through advocacy," she says. "We use the media by doing advocacy. In civil society there are those who use social media (for lobbying and advocacy). But those who are analogue like us, we do community relations and write letters for instance-on legislative bills."

And yet PeaceNet has come to be synonymous with a number of digital communications initiatives designed to offer practical ways in which the common people might get involved in the political process. Some of the more famous ones apart from Ushahidi-which, like it, almost invariably combine online platforms and mobile telephones-include in-house projects that led to the creation of Usalama (Swahili: security), Sauti Mashinani (Swahili: voices in the grassroots) and Uiano (Swahili: harmony/conciliation).

The Usalama Reforms Forum aimed to drive reforms in the national police force, a key prop in the Moi-Kanu regime's longstanding policy of disenfranchising the people. It produced documentation to back up accusations of widespread human rights abuses against change activists. PeaceNet created an online platform and arranged for a toll free number where people could report police abuse. Gichuki believes that this sort of social media activism has brought about significant reforms in the national police force and in other public institutions. "If judges are very corrupt, eventually those details will pop up on social media," he says. "If Kenyans 
think poorly of the police force, they do not hide it on social media. They take pictures of them giving bribes to police. They record these conversations of policemen taking bribes and they upload these. And so, because of this, the police are aware. People-policemen refuse to take bribes by M-Pesa today. They say, no, no, don't give me money by M-Pesa! Don't give me bribes by M-Pesa! Because it leaves a trace, right?"

The Usalama Reforms Forum alone counts up to 11 major national and international partners: the Open Society Foundations; The Netherlands Government; the Kenya National Police Service itself; the Altus Global Alliance; Research Triangle Africa; Saferworld; UN Women; the Kenya National Commission on Human Rights (KNCHR); the British High Commission; USAID's Chemonics programme; and the Commonwealth Human Rights Initiative. The various sponsors saw an opportunity to use social media to change various institutions. The Kenya National Police Service says it is "working together (with Usalama) to change the standing orders of police, improve police accountability, and engage in proper planning and budgeting strategies". The KNCHR, a legendary local civil society group, says its work with Usalama aims "to promote rights-based approaches to policing, including on implementation of police reform legislation".

The social media component has been associated with other lobbying, advocacy and mobilisation strategies as well. 
Uiano was formed as an early-warning system to prevent election-related violence. Similarly to Usalama, an online platform and a toll-free number were set up so that members of the public could send messages from potential flashpoints. Mutoro says that the Uiano telephone number has been a big help: "It has sometimes helped to quell tensions in particular areas. It has also helped to prevent the escalation of conflicts and casualties. The SMSs have been very helpful." She says that Uiano works closely with the security forces: "We will usually confirm and verify our information by calling (an agent on the ground). An example was during the 2013 elections. Once we have verified the information, we call in the security forces."

Mutoro gives examples of places where they were able to intervene in this way. These are the informal settlements of Kiambiu, Mathare, Korogocho and Kibera in the Nairobi area. She says: "We have structures in place on site-young people that we work with. For example when there was this thing about the court ruling (when Odinga challenged the validity of Kenyatta's election in May 2013). We had information about various youths wanting to do various things-marching and so on and so forth. We then got the security forces to intervene."

Mutoro notes the significance of the demographic that this strategy has got involved. "These had been youth who had been involved in crime-who had been ignored," she says. "But after engaging them they became agents for positive change. They had mobile phones, working as election observers. Two worked as data clerks." The field 
agents would send text messages to the clerks in the data centre who would then call back for further information.

Mutoro notes that the mobile phone is more important to PeaceNet's work than the computer. "The people we work with in the informal settlements are more likely to have a (mobile) telephone handset than a computer," she says. "They are also likely to be illiterate, but they can use a phone. The same goes for people in the grassroots. You can talk of 'mobile citizens' as opposed to just digital citizens."

She adds: "We use bulk texting. If you get a toll free number, with that you are able to disseminate as much information to as many people as possible. You are also able to get many more people involved. Using the number does not involve costs."

Sauti Mashinani's brief goes beyond the electoral cycle. It, too, has a dedicated online platform and toll-free number where the "grassroots voiceless", as Mutoro put it, can participate in "peace actions". This number is shared with particular community leaders in the grassroots who form what PeaceNet calls the District Peace Committees. This initiative also links in the police. In this way, Sauti Mashinani has been shaping public institutions at, and from, the grassroots level. Sauti Mashinani also has a Facebook page, as also do the other PeaceNet platforms. 


\section{CHAPTER 5: ISSUES AND OPPORTUNITIES}

Social media has created opportunities for telling involvement in public conversations hitherto unimagined by ordinary Kenyans. However, it has also created new problems and magnified old ones. In this chapter, we examine these issues and opportunities.

Among experts the general consensus is that there is something of a demographic pyramid based on the way that media is shaping popular participation in Kenya's political institutions.

At the top is the 8 per cent minority-approximately five of 40 million-who use social networking sites, according to Kamau. This 8 per cent, as Kamau observes, comprises the most influential people in the country: politicians, journalists, academics, business people and, to quote Gichuki, educated and "very opinionated" young people. Generally these people live in the cities. Those in the countryside look up to the urbanites, usually considered to know what is best politically speaking. These urban elites also have access to mobile phones, radio, television, and the print media. In fact, they it is who decide the content of mainstream media.

At the base of this pyramid is the vast majority of Kenyans. The closest that they come to networking through social media is through texting. Radio is the most important medium for this group, although some experts say that the mobile phone would appear to be taking its place. The advent of FM radio-including in many of 
the country's 68 ethnic languages-has opened up the population to mass messaging in a way that was not possible in the days of amplitude modulation (AM) and SW radio and of state monopoly in electronic broadcasting. Mobile phones have also extended the reach of radio because more and more cell phones have a radio component. To a lesser extent, the middle-to-lower reaches of this pyramid comprise demographics that increasingly have access to TV—in English and Swahili.

That the lack of significant Internet penetration mutes the impact of social media was advanced by Franceschi and Muindi, among others. Franceschi says: "For the average person, you $-\mathrm{I}$ don't think so (that social media affects their political participation). The average person in Kenya is a person without access to electricity. Only 20 per cent of Kenya is connected to the power grid. Now, is it (social media) a source of empowerment etc for the young people in urban centres? Yes... Certainly they (social media) are helping public participation (in the political process)."

Says Muindi: "When you look at most of Africa, radio remains king. This is because of poverty, illiteracy, and lack of electricity outside of most urban centres. There has been a massive surge in vernacular programming (ie, in ethnic languages)."

However, whereas Kamau underlines the limited impact of social media as a tool for political mobilisation per se, he nevertheless highlights the significance that it has as an increasingly crucial site for political debate. "By the time I did my study, we only had about 3.6m Kenyans on Facebook at that particular point," says Kamau. "That 
was last year around November. That is about 8 per cent of the Kenyan population. It is significant because you might find that the people on social media are opinion leaders because you find journalists, you will find some scholars, you will find public figures-these are people with influence. So the 8 per cent of the Kenyan population—it may be small but it could be significant."

Ogoda terms the members of this group the "key informers". She and others paint a picture that seems to suggest a sort of dictatorship of the chattering classes. "There is a disconnect," she says. "The digital citizen has a greater opportunity to air views and make their voices heard-and feelings known. The analogue citizen, who are actually the masses -70 per cent or so, rural-based-are-in the end are almost like disenfranchised, in the sense that the digital group come influencing and telling them this is what we want and this is how it is out there and you must just come along." Ogoda has an issue with the influence of this plugged-in group: "We call them in the (political science) department, 'key informers'. How key is key? Who made them key? What is the scope of their being key? They are the ones operationalizing the words and implementing the operationalization and carrying the wishes of the others... So to some degree the digital citizen has greater clout, and if clout can be called influence simultaneously, then the rural folk say, ah, the people from town know best. They know what the government is saying. They defer in their decisionmaking processes and rationality. Yeah, they defer." 
As we have seen from Mutoro's observations earlier, the mobile phone is of huge significance in digital communication in Kenya. Muindi adds: "The mobile phone is simple and affordable (as opposed to a computer). It costs just 1,000 or 2,000 shillings (CAD 12.7 or 25.5). Most people see the mobile phone as something to send text messages with. Multimedia capabilities are a new development. Text messaging has become predominant in social communication because Internet and multimedia are expensive."

The mobile phone, which has come to link the two reaches of the pyramid, has become ubiquitous in the country ironically owing to the institutional sins of the country's one-party era. Says Muindi: "Mobile telephony came in as a result of the collapse of landlines. The lack of proper management by greedy politicians led to this collapse some 15 years ago (ie, around 1997)."

This demographic pyramid also has an age and educational dimension. Younger Kenyans are more likely to use social networking sites than their elders, who are more likely to listen to the radio. To a large extent this has to do with differences in education and economic standing. Younger Kenyans are more likely to have been to school (and, therefore, to be able to afford access to and use social networking sites) than older Kenyans.

But Ochola disagrees with Muindi on the extent of social networking sites use. He says that the youth, who are the majority in the country, usually "own a phone or 
two", and that those phones as a rule can access the Internet. He says that in most major cities—the likes of Nairobi, Mombasa and Kisumu—people are going online to critique "very many" government policies.

Gichuki observes that the Kenyatta camp has been astute in taking all of these realities into account when putting together their communications strategy. The stunning and largely unexpected success of the "digital" UhuRuto ticket partly has had a lot to do with the highly professional analysis and strategizing led by experienced international pollsters.

"Of course there is a tendency for a certain class of Kenyans-middle class Kenyans and upper middle class Kenyans-to be very vociferous on social media but not anywhere else," he says. "And it is easy for the government to ignore that groupyou know, entitled, middle class, opinionated-because as far as government is concerned-at least I get that sense from this government-its mandate doesn't come from the middle class. Its mandate comes from the ordinary class (read: lower classes) with whom ethnicity is a big issue, with whom you can stoke the embers of sovereignty and they feel very passionately about their leaders. So I think it is that with certain issues, social media does inform policy."

Gichuki says that Kenyatta's communications strategy after the final status conference on his International Criminal Court (ICC) case, in 2014, demonstrated this nuanced approach. "It is very clear when Uhuru Kenyatta landed (from The 
Hague), he went to (the less affluent) Eastlands," he says. "He didn't go to (the more affluent) Westlands. He went to Eastlands. His whole tour from the airport went through Eastlands. Which essentially means that he is very clear for which constituency he is messaging. He didn't go-went to Eastlands where you could see big crowds of young people who were willing to stop what they were doing and come and meet him as a returning president. The question is, had he gone to Westlands, would there have been such a large crowd? Maybe, maybe not. It is clear to him that this constituency-that they may not be active on social media, and he goes to them directly. You have at least now an attempt to respond to both constituencies."

Gichuki observes that this Eastlands-type demographic is also more likely to get its news through radio. "There is that constituency that may be offline, but for whom the key shapers of debate may be radios, and call-in shows where the guy is working," he says. "He is not checking his Facebook status in the yard in Gikomba (the country's largest open-air market, located in the Eastlands of Nairobi). He does not have the time to check his Facebook status. But there is a radio that is on the whole day as long as there is a political commentator there or a favoured radio presenter who shapes the tenor of the debate.

"So unlike in the US and more developed Western societies, where you can expect that a significant class of people are middle class and therefore the opinion on social media is very important, in Kenya you have a sliver which is very opinionated, which is very educated, which is part of the agenda. Then you have many idlers on 
social media. And the government—-this government has been very savvy in shaping its messaging. Who are we directing this (message) to?"

Some, such as Mutoro, Abdi and Muindi, have a pessimistic view of the reach of social networking sites.

Says Mutoro: "In Africa we have the literate and the illiterate. Development is not the same. The mobile telephone is more convenient (for our work)."

Abdi says: "Increasingly we have seen mass mobilisation, especially on Twitter and Facebook, not unlike in the Arabic Spring. Social media is fractured along ethnic lines. We haven't seen use that is at a national level. You are more likely to see (ethnic) Luo bloggers and (ethnic) Kikuyu Facebook activists (each championing the perceived interests of their respective ethnic group). But you are unlikely to see political mobilisation (on the same scale) as you saw in the Arabic Spring."

Muindi is even more dismissive of the influence of social media networking sites. He says: "(In Africa,) most social networks use the European languages and the dominant local languages-Hausa and Pidgin for example. Politicians benefit from them. They use them and then when things get bad they deny involvement. Bloggers are nothing. You can be an important blogger, but in Africa you are nothing. A lot of political activists and groups have Twitter and Facebook accounts. Some have a few hundred and others a few thousand followers. As a result they will be followed by 
the media and spy agencies. Twitter and Facebook is catching up, but it is not as powerful as it is in the West."

Among others, Ochola and Ogoda have a different view of things. They see a situation where the digitally savvy have great influence on the lower reaches. Ochola describes a situation where, much like in the olden days when "with-it" urban dwellers travelling upcountry were expected to enlighten their kin in the village, today's "digital" urbanites enlighten the rural masses with wisdom gleaned and refined on social media sites and texted or phoned to eager ears in the villages. According to Ochola and Ogoda, these digital urbanites basically make up the minds of their rural kin, which makes the former a precious resource for discerning politicians.

Ogoda and Ochola explain how social media has come to fit in nicely with an age-old culture of communication and community-building based on orature.

"Whoever takes that type of approach (that social media does not affect opinion upcountry) is false," says Ochola. "What happens in Kenya is that every morning and every evening, I actually talk to the people in the village. The arrangement in this country is that a child (goes to school) in the village and comes to town to look for a job. The lucky ones actually get a job and start working. Now when they work, they are constantly in touch with their families. So each morning and each evening, they actually update their families about what is happening in Nairobi. And a simple 
conversation will start by: how are you my son? How did you wake up? So what is happening in Nairobi? And I tell you, What is happening is that Raila (Odinga) was beaten (Odinga was caned publicly without provocation by a member of a crowd he had been addressing in 2014). Why was he beaten? Chances are that because of the jam in Nairobi I did not watch the news. I have gone with what went on social media and what went on social media is that Raila was caned because he was dancing with another man's wife. So, we were told that he was caned in Kwale because he was dancing with another man's wife. And that is what I have actually picked up from social media. So that is what I will be telling my family or even my colleagues-my peers-at home. Now that message, once I tell that person at home, he is actually going to spread it. When I tell my mother the same, she is going to tell her friend. Her friend by word of mouth will tell another friend of hers. And within a very short period that message has actually spread. My mother who cannot use Internet is actually going to be fed on what is happening on the Internet by me. And she is going to spread that word, and also another person is going to spread that word, based on what I have actually told them, and it is solely depended on which side of the coin in terms of politics I am actually supporting. It is as simple as that... People are having a very different version of what they are supposed to have."

Ogoda disputes the idea that radio is king, at least as far as Kenya is concerned. She has this to say on the same "mythinformation" process described by Ochola: "The folks in the rural area have two main uses of the phone: one to keep in touch with what your family and friends are doing and thinking. But besides, Kenyans have 
always been known as a people that when we talked before the social media we used to talk about the usage of radio in Africa. And you will find one radio and the whole village collects about it. Now it is what is going on-even the illiterate has the telephone-the hand-held thing-programmed to just punch certain things. Now, what is the latest today? And that is how they are spending that time which used to be spent on the radio to know and keep abreast with what is going on. I can assure you that somebody in Sori, Fagano Island and Migori (western Kenya)-they already know all that what went on at The Hague (ie, Kenyatta's status hearing at the ICC) because somebody has had to sambaza (colloquial Kenyan Swahili: share by mobile phone) it. And some people cannot sit still until they have punched the phone. They may have no money for sugar, but sambaza the 20 shillings $(25$ cents in CAD) just to call so and so to find out what is new. Please call me back and tell me what is going on... There are those who just must know the goings-on, the latest."

She adds: "That has an influence-has the spill-over effect that the person being told what is going on doesn't process their own thoughts about this issue. More often than not you will hear them saying, Even so and so told me that that is the way it is. It is not that I thought it through and have decided that that is the way it should be. Even so and so-I talked with so and so the first thing in the morning from Nairobi and that is the way it is. I talked to so-and-so in Mombasa and that is what the people there are saying (ie, the rural dweller quotes their urban-based relative as an indisputable authority and an infallible source). So when you are talking about political mobilisation... it has that dynamic and that capacity for use for political 
mobilisation whether truthfully or rhetorically, whichever it is, or whether manipulatively... We have just gone to the extent of affirming what Cicero said, that there is nothing so horrible that rhetoric can't make it seem acceptable to the masses... It is misuse of the masses."

As we have seen, what the digital urban dwellers pick up online, they feed to the people in the village. This, according to Kamau, informs Kenyatta's strategy of "guiding the conversation" on social media sites. Ochola talks of "Internet soldiers"-in effect keyboard warriors whose express purpose is to set the agenda online and shape the policy outcomes offline.

\#UhuRuto has proceeded to show the way yet again, for better and for worse. The Jubilee Social Media Cabinet, a dedicated team of up to five individuals complete with a "president", is what Ochola calls "Internet soldiers". According to Ochola, this group is responsible for the completely different way in which the public physical attacks, respectively, on Odinga and Kenyatta (the latter had a shoe thrown at him during a visit to Odinga's western Kenya turf) were received by the public. Ochola said that perceptions of the attack on Kenyatta-which predated the attack on Odinga-were more negative than perceptions of the attack on Odinga. This, according to Kamau, is proof that the Jubilee Social Media Cabinet is working-as also is the strategy of maintaining a presence in social media by the president and the deputy president. 
According to Kamau, the Jubilee Social Media Cabinet comprises Mugo wa Wairimu, its president Pauline Njoroge, and Steve Kewa, among others. He says that although Joel Mithamo may not officially be part of it, he is closely associated with the "cabinet". He says that the group's work is "to guide (and) shape conversations on social media in favour of the government".

"So when you have-want to say something negative against the government, they are there... defending the government always," he says. "And they are doing a good job I would tell you. The minute something happens they are spin doctors, you would just see the political spin. And I know that they are doing it with the full knowledge and support and perhaps even financial support of the government. I am sure, because they have a lot of access to information. You can see them updating.

"Now these are people we did not know before. But they are voices and they are working and I know they have access to the powers that be. I know they have that kind of access. And they are doing a lot of work... That makes Jubilee very strong on social media. Because Cord has a few people who try to do that, but it is not as organised as these guys."

Says Ochola: "We would want to see the president actually reining in his so-called bloggers_-or his so-called Internet soldiers-reining them in hard as an example that indeed he does not condone the spewing of hatred." 
Ochola is in no doubt about the effectiveness of the so-called social media cabinet. He says that the difference in public perceptions of the physical attacks, respectively, on Kenyatta and Odinga had to do with the highly coordinated work of the cabinet on social media. "It's systematic," he says. "I update, you update-you come up with your memes and everyone comes with funny caricatures. And within a very short period the Internet is flooded and a topic is trending. And then it becomes difficult for someone to make a subject (go away)."

Ochola gives another example of the triumph of the "Internet soldiers". He says that the news that Rwanda's Paul Kagame and Uganda's parliamentarians would be accompanying Kenyatta to The Hague for his status conference were "a lie" planted in social media by Jubilee's Internet soldiers. Kagame promptly denied the reports, carried by several Kenyan media outlets, noting ironically on his social media pages that this was news to him.

"That tells you the power of social media," says Ochola wryly.

Gichuki and Ogoda, like Mutoro, Kamau and others, note that the ruling coalition sees social media as a very important resource in determining what the public mood is and what the more influential sections of the population think in specific contexts. Social media, they aver, has become a key listening post for policymakers looking to keep important sections of the population—-the digital citizenry—onside. Kenyatta pioneered this approach while still minister of finance. He famously invited his followers on Facebook to help him prepare his budget by suggesting items that 
should go into it. The result was quite mixed, with many ordinary members of the public taking great pleasure in the rather uncommon opportunity of contributing to an important policy. But some opposition politicians and members of the press saw this as mere politicking, questioning both the wisdom of inviting the hoi polloi to weigh in on such heavy matters of state, and the very idea that Kenyatta would really consider any views offered by the general public.

But Gichuki says that Kenyatta is genuinely interested in what the public have to say on social media. By way of example, he says that Kenyatta relied heavily on social media feedback when deciding whether to attend his highly controversial status review hearing at The Hague in 2014. The hearing was intended to determine whether there was sufficient evidence, old or new, to continue the case. Many Kenyans were opposed to his travelling to The Hague to attend the hearing in person, fearing both for his person, the reputation of his office, and the country's prestige. Says Gichuki: "I think the importance of the digital citizen—and necessarily they are a younger citizen, but it has grabbed everyone really-everyone has a sort of account-is that it is now very clear for the framers of policy what the mood of the people is. Take for instance the question about whether Uhuru Kenyatta should attend his status conference at The Hague or not. In a pre-digital world he would have to rely on an NSIS (National Security Intelligence Service) report about people who've walked around in the streets and in bars-what are people saying? Would it be a wise political move for me to not go? Today he only has to look at the media flow on a social media account to gauge the mood of the citizens. And this is true of 
every other institution that directly affects the Kenyan people. Do Kenyans want the (mooted Chinese-funded and built) railway or not? And this feedback from social media then influences the responses by those individuals." Kenyatta went to The Hague where he saw his case suspended indefinitely.

Ogoda gives a different example. In early 2014, opposition leader Odinga spent several months in the US, where he lectured. His party and its coalition partners then prepared a grand public reception when he returned home. The Kenyatta camp became nervous. The hashtag \#BabaWhileYouWereAway became one of the most widely used in the country's nascent digital history (baba is Swahili for father)— almost up there with the perennial \#SomeoneTellCNN. The people used the \#BabaWhileYouWereAway hashtag for a vast variety of reasons: national soulsearching; criticism of public figures and institutions; humour; public mourning (there had been a spate of terrorist bombings); and the rather unsavoury but standard trading of insults and accusations across ethnic and political divides. When the country's chief of police-called the inspector-general (IG)—banned the rally that had already been licensed to take place at Uhuru Park in Nairobi, the country was in uproar. It was clear to everyone that the illegal ban was politically motivated. The excuse that the rally could become a target for a terrorist attack-which in reality never materialised—was condemned as a political sleight of hand. The rally did take place. 
Says Ogoda: "The current leadership—the executive-are very responsive to social media. I remember when Raila came back from the US demanding national dialogue. First of all he was coming and he is coming - the meeting at Uhuru Park (in Nairobi) was banned. Wait until people started the outpouring on the social media! The decision was changed overnight in response to what the Twitter and the Facebook fed to the president. Not to the inspector-general (of police)—-to the president and deputy president (Ruto), issuing orders to the inspector-general that (the public meeting) must be allowed. It was changed overnight." The rally became one of the largest ever held in the city.

Ogoda offers another example. She says: "Were you here as the debate as we know-this fellow who flogged Raila? And you saw now him demanding the balance? He was paid 30,000 (Kenya shillings-CAD 380) down payment by (Nairobi Senator Gideon Mbuvi Kioko, more commonly known as Mike) Sonko and now he wants 70,000 (CAD 885) from Sonko (a Kenyatta ally), the balance that was left. And then that came out in the newspaper. And the social media painted the city red-abuse and what-have-you."

Mutoro also gives an example of the influence of social media on decision-making at the highest level. During one of the country's national holidays, a helicopter was commissioned to fly a copy of the president's speech to a distant part of the country. The reading of the presidential speech by a proxy has been a standard practice in the celebration of national holidays ever since the post-independence days. The 
news leaked out somehow. Social media was in uproar and the president's social media pages and handles felt the heat. The plan was scrapped.

During the inauguration of Nigeria's President Muhammadu Buhari on 29 May 2015, President Kenyatta was forced to abandon plans to attend the ceremony-the only peaceful handover of power between two democratically elected leaders in Nigerian history-following an outcry over the size of his proposed entourage. State House proposed upwards of 80 officials. With typical responsiveness, the president found a way to distance himself from the proposed list and went as far as to ask Deputy President Ruto to travel in his place.

Other politicians have learned from Kenyatta's use of social media. Zainab Deen, the online editor for BBC Swahili based in Nairobi, Kenya, notes that major players such as the governor of Kiambu County, William Kabogo, have taken steps to have members of their staff trained in social media. Ochola says that Kenyatta University has been receiving staff who come for short courses in social media and digital communication-in particular from Nyeri County (the Kenyan county is the equivalent of a Canadian province). Muindi says that the social media impact of a protest against exorbitant salary hikes and expensing by MPs, led by socio-political activist and blogger Boniface Mwangi, led the MPs to adopt social media as an essential part of their own political mobilisation and image management. Mwangi led a group of protestors on 13 May 2013, who threw a pig's head at Parliament Buildings to protest the greed of politicians. The politicians were shocked. 
"Politicians learned that they could benefit from social media. They now use social media and just deny that they are the owners of a given page or handle when things go wrong," says Muindi.

Deen, who has since joined CCTV Africa, underlines the point, saying that the influence of digital citizens has a greater impact on the political process. "Well yeah, because just through social media these days, people can actually organise protests on social media," she says. "They are not protesting on social media. But they are getting out to people who have the same mindset with them to urge them to come out and demonstrate with them on the streets and sort of influence the political process... That is what (Mwangi) did... He is a blogger also, but very active on Twitter, Facebook... And people went out on the streets. And that is now where social media comes in-or digital media comes-influencing the political process through social media. People read, people comment, and then go onto the streets and support the activists on social media."

Other public institutions have also adopted social media. It has become common for information of public interest to be tweeted or published on Facebook by government departments, agencies, corporations and other entities. The police and the military do it often. The military, in particular, made a bit of media stars out of a series of spokesmen who became prolific tweeters and Facebook users. The Somali militant group Al Shabaab would have its revenge in 2014 when it hijacked the army's Twitter handle on two separate occasions, posting its own messages using 
the enemy's online noticeboard. The hacking apart, the militants and the Kenya Defence Forces (KDF) spokesmen also had a series of pitched battles on Twitter in particular.

Wrote the Associated Press's (AP) Katharine Houreld on 12 December 2011: “Kenyan soldiers and members of an extremist Islamist militant group have been fighting each other in Somalia since Kenya invaded two months ago. Now, their spokesmen are taking the battle onto Twitter, with taunts, accusations and insults being directly traded in a rare engagement on the Internet."

In response to the KDF spokesman, Maj Emmanuel Chirchir, threatening to bomb concentrations of donkeys on suspicion that the latter were being used to ferry weapons and munitions, an unnamed Al Shabaab operator tweeted their derision. They said:

"Your eccentric battle strategy has got animal rights groups quite concerned, Major."

Stung, Maj Chirchir responded: “With Al Shabaab joining tweeter, let's take fight to their doorstep."

In analogue times, the Kenyan military was one of the country's most impenetrable public institutions. La Grande Muette (the Great Mute One), the expression the French use to refer to their own military, could have been invented for it. Now here it was, publicly—and virtually—slogging it out with a foreign enemy and providing a near blow-by-blow commentary on its operations to its local and foreign publics. This development, unimaginable in the 1980s and 1990s, became a boon to various 
actors in Kenya. Members of the public and low-calibre institutional actors could now weigh in and let their sense of how they felt things should be going known within the highest reaches of a major public institution and in a moment of crisis. Kenyan human rights activist Hassan Omar Hassan told Houreld that "the flurry of tweets obscures the paucity of information about actual operations by the Kenyan military since it entered Somalia". But, as noted by EJ Hogendoorn of the ICG, "The tweets themselves will not be entirely accurate but it will allow analysts to triangulate that information and come up with a more accurate picture of what is really happening."

The influence of social media has not been felt by politicians, bureaucrats and soldiers alone. Legacy media itself has had to change to adapt to the times. Notes Kamau: "There are certain stories that start on social media and end up in mainstream news. There are things that will be discussed on social media for a while. You see that it is on Facebook or on Twitter. You see it's there but the mainstream media has not yet picked it up or maybe for one reason or the other they are ignoring it, and then eventually you see it being covered." He adds: "I know churches that are using that actively. They even have people whose work is to actually-like the church I attend is digital. Every Sunday you will see them trending-whatever is being preached. There are guys doing that and flooding the social media platforms to make sure the information is there. So in a sense they say 
they are preaching. They are reaching out to people." The church is a high-profile political actor in the Kenyan context.

Ogoda says: "These days you say something, it is on social media immediately. And turn on the TV in the evening-Citizen (TV) they are on Twitter telling us this and that. Facebook they are telling us this and that. Every time there is a big question or topic, all the TV stations or channels, they have their Twitter on, and their Facebook on. And they must conclude by saying what percentage (of viewers) are saying what where... (Social media are) universally accepted already. The newspapers have Twitter handle, they have Facebook. The TV stations have that and they are summarising and informing the public... It is across the board... (Other institutions) can be contacted on Facebook as well because they need to know what their constituents think about their services."

Mutoro says: "Whatever is trending (on social media) tends to get the attention of most people. The mainstream media is falling into step. Take NTV's The Trend, a programme that airs after the $9 \mathrm{pm}$ (prime time) news on Fridays. It points out all the trending issues for the past week-in particular according to the impression they made on social media."

Deen says that what is going on online has become so important that the BBC's strategy is now geared towards making all its content compatible in particular with mobile devices. "It is a factor because you are talking to people who are mobile," she 
says. "And in East Africa actually, quite a high percentage of people own mobile phones." The numbers for Kenya, according to a 13 February 2014 Pew Research Center report, are 82 per cent mobile phone ownership and 37 per cent Internet access. The report said that 76 per cent of Kenyans went on social media once online.

"If you look at our content, we were only desktop until we realised most of the people who accessed our content were actually accessing it through mobile phones," says Deen. "So what we had to do is we had to be friendly to them and sort of convert our format of digital and online content presentation into a sort of a mobile (telephone) format where people access it because mobile phones are there, first of all. People access everything on mobile phone these days-radio, reading content online, or Facebook, chatting, sending messages, sending short videos-everything is on mobile phone. So when we figured that people were accessing our BBC Swahili content on mobile phone, we had to adjust to what they want or what they like or how they access our content. So it is quite friendly. It is called the 'responsive design'."

Deen describes some of the aspects of the new mobile-ready format they are using: "It is easy, like when you read a story, the content is quite large, it is friendly. We don't make it long. It is quite short. Because we figured people sometimes get bored reading long articles. That is what the desktop format was like." 
Deen says that this reality has not hit home with just the $\mathrm{BBC}$, but with all the players in the East African media. She says: "They already have (ie, mainstream media have migrated to social media)! If you look at Twitter-from Uganda—right from Uganda-New Vision (that country's largest daily newspaper) posting links of stories every now and then. In a day you can get maybe about 100 or 200 tweets from them. Standard Digital Media, Standard Media, Nation (Media Group), BBCeverybody is on social media. They actually have migrated because that is where the people are today. Somebody holding their phone all the way from home (ie, upcountry)-you obviously want to get that person there. So you will not only put your stories online and leave them there: you will take them and send them back to social media and then direct the traffic from this guy onto-back to the online stories. So I think that is what all media houses are doing. And that is how much social media and digital media have influenced mainstream media."

On 21 January 2015, BBC News Online announced major changes to its news strategy. An article on the website announced that it would provide a more "personalised" service. It also announced that the changes were part of a wider "shake-up" of its online presence, which would include major adaptations in its presentation and appearance. On 23 March 2015, the BBC synchronised the interface of its desktop format with that available to users of mobile devices. The organisation had given clear pre-eminence to users of mobile devices not just in Kenya, but around the world. 
This is a trend that Kamau sees extending to many other parts of national life. "The advantage with Africa-because we did not have the whole place wired up with landlines, that is why mobile telephony has experienced rapid growth because people want to communicate," he says. "The penetration is 28 million... 28 million out of 42 (million people)... There is huge growth."

Of course social media and mass texting have raised serious concerns. The biggest is social cohesiveness. The country, critics say, has been fragmented along ethnic and sectarian lines. As one member of the Kenyan public put it in a June 2015 Facebook post, there are a lot of people "vomiting sludge" in social media.

Says Mutoro: "You can understand our concern as a peacebuilding organisation. Negative ethnicity is a concern. There is manipulation of the various ethnicities. It (social media) is a good tool, but it is also dangerous. This has not been properly addressed." The phrase "hate speech" is now common. Mutoro is concerned. "People have taken hate speech a notch higher," she says. "We are seeing negative ethnicity, propaganda and terrorism (propagated on social media). Conflict between Christians and Muslims is being played out on social media. Social media is like a free-for-all. There just isn't enough control."

According to Mutoro, hate speech on social media has become a major concern for the NCIC, which is led by former National Assembly Speaker Francis ole Kaparo. The commission was created in the wake of the post-election violence of 2008 to 
address inter-ethnic conflict. "They (the commission) have a say on this," says Mutoro. "But they have little control over what actually happens on social media."

The authorities may have more control over hate texting, but the medium remains vulnerable just as it has been in the past. Muindi says: "The way to achieve the most social communication is through bulk texting. Write message, click, and hit 'send'. If you are doing things legitimately, you look at the required law, pay what you need to the operator, and proceed. But some players can commandeer these operators and send texts." Muindi explains: "Take cybercriminals. They can hack (mobile telephone carriers' infrastructure). Determined political groups can also do this. They can patiently collect mobile numbers online and use them. They would only need to pay 10 university students to get hundreds of numbers manually and you can send messages to these numbers. There are new Chinese and American technologies that make this possible."

Muindi underlines the primacy of bulk texting in the new political environment, saying: "Political mobilisation works especially through radio and (bulk) texting. Because of the improving literacy rates, new social networks like Facebook and Twitter are coming into play. They are also used to mobilize people and (deliberately) create tensions. They can also be used to rally people behind causes. They remain unregulated." 
Muindi suggests that part of the reason social media and other digital media remain dangerous is because they are policed unevenly. He says: "Hate speech is rife partly because what is called hate speech depends on who is defining it." He says that whereas digital media has provided added opportunities for popular participation in the political process, it has also become a potential tool for oppression, adding: "There are a lot of political activists and groups that have Twitter and Facebook. Some have a few hundred and some thousands. As a result, they will be followed by the media and spy agencies."

A more recent danger has been terrorism. Muindi says: "Some other groups using or hijacking social media and bulk texting are terrorist groups. For instance, Al Shabaab's Twitter account remains unverifiable. But there exists handles that tweet for them."

Abdi, an expert on terrorism, has strong words against the way digital technologies have affected the community-building project that is Kenya. Abdi says that the 2008 post-election violence changed the way social media was used in the country. "There have been a lot of ethnic bigots on there since 2008," he says. "It is now not just a benign thing, but also a repository of all the bad things we thought we had gotten rid of. Social media can be said to be a very important tool for national, social and business life, but we cannot overlook its bad effects." 
He says the freedom of speech that initially characterised social media has not led to the best possible outcomes. "Social media is fractured along ethnic lines. We haven't seen use that is at a national level. You are more likely to see (ethnic) Luo bloggers and (ethnic) Kikuyu Facebook activists."

He says that the ethnicisation of social media is not an accident, but the result of deliberate manipulation. "Kenya is a deeply divided country. It is fragmented along ethnic lines. Social media is being used to push ethnic messaging. The culture is changing the medium rather than the medium changing the culture. Radio did change the culture-not so social media. The democratisation of ICT has not changed the fragmented nature of Kenyan politics."

Kenya has traditionally been known to be a country where religious tolerance was taken for granted. On any given day of the week in the 1990s and 2000s, you could find Muslim and Christian preachers just a few dozen meters from each other proselytising loudly at Nairobi's historic Jeevanjee Gardens. But this has now changed. Since the 1998 bombings of the US embassies in Nairobi and Tanzania, the traditional tolerance among the country's many religions-the largest of which are Christianity and Islam—has slowly deteriorated. Years punctuated by the occasional bombing were followed by more frequent attacks when Islamism took hold in neighbouring Somalia as first the Islamic Courts Union and then their offshoot, Al Shabaab, tried to impose their strict interpretation of Islamic law on that country. 
Kenya would soon be sucked in as the country was forced to send in the military as the Islamists increased their attacks on Kenya.

Says Abdi: "Kenya has a serious radicalisation problem on the coast and in the Northeast. This is partly driven by the Internet and social media. Mercifully the reach of the Internet is still limited. The more its reach expands, the more cyber jihadism is going to spread... The pathway to radicalisation in Kenya remains mainly the mosques and the madrassas—not cyber jihadism."

Abdi says that unlike in the West, where cyber jihadism is more entrenched due to better ICT infrastructure, Kenya is only now beginning to see a nascent form of ICTmediated radicalisation. "Al Higra and MYC (Muslim Youth Centre) Kenya, who are based in Majengo in Mombasa, are becoming adept at using social media," he says. "These groups are loosely connected to Al Qaida. Al Higra, in particular, is becoming adept at using Twitter and Facebook to undermine government strategy. Their links keep on being shut down, but they always reappear."

It was these groups, Abdi says, that went on social media websites to applaud the Westgate terrorist attack in Nairobi in 2013, terming it brave retaliation for Kenya's killing of Somalis.

Says Abdi: "Kenya has a double problem: social media is being used to undermine social cohesion between Christians and Muslims-to radicalise-and to widen the 
ethnic divides... Social media is creating social division, exacerbating social hate. But so far it has not been used to mobilise ethnic constituencies for violence."

Abdi says that part of the problem is that the government sees the dangers posed by social media as "benign". He says that the government has failed to pick up "the underlying menace of what appears like harmless banter" on social media but also admits that attempts to police social media are likely to be ineffectual because "the elements under surveillance disappear into the Dark Net. The best solution would be to come up with a counter-narrative to radicalisation and ethnic messaging."

Ochola says the government is yet to quite come to grips with the challenges posed by social media. “This country doesn't have laws that govern social media or even Internet use," he says. "Basically it doesn't. I am told that they are actually now trying to craft some laws here and there to try and actually streamline that sector. But the fact of the situation on the ground-and of course I would say now on the (Facebook) wall as it may be-is that it has entrenched ethnicity, it has entrenched hatred amongst political players and supporters in the country. For instance, if you want to know how bad the situation is in terms of ethnicity and hatred on social media, all you need to do is that post something that has been done by a different ethnic group-an ethnic group that is not perceived to be politically correct, or is politically incorrect. Now what will happen is that people across the political ground, the first one or two or three comments will be genuine comments. Now the 
comments that follow after-in fact after the fifth comment is basically abuse aimed at one ethnic group against the other."

Ochola also agrees with Abdi with regards the heightened dangers of sectarianism posed by social media. He offers scenarios as well as examples. He says:

"(There has been) a very worrying trend that I have actually seen: there are ongoing clashes in the Muslim world. And the latest one actually is in Iraq. There are actually photos showing ISIS (Islamic State in Iraq and Syria) soldiers kicking Christian babies. They (social media posters) are actually saying that these are ISIS soldiers kicking Christian babies. Now whether-no-one can authenticate such claims. But remember those clips are already on social media and we can actually access them. It is sowing seeds of hatred between Christians and Muslims. The other thing is that those situations going on in those areas-those videos are actually on the walls. And actually they are being shared over and over again on social media. In Kenya! If you check on the walls you will see them. So basically what it means is that they are sowing seeds of discontent between two different religious groups. When there were repeated terror attacks in the country-those sporadic terror attacks in the country-you could see people actually attacking the Muslim community. Were it not for our leaders who actually put their feet down and stood their ground to ensure that we continued to stay as Kenyans in this country, then we were on the brink of actually having to fight a religious war." 
He highlights another instant in which sectarian sentiment on social media nearly led to violence. He says untrained "people who wanted to be journalists and cannot be journalists" spread rumours online that "Christians are chasing Muslims in Eastleigh". This led Muslim youths to arm themselves, creating a tense situation in the east Nairobi neighbourhood. Similarly, he says, a section of posters online cast the 2014 crackdown on illegal immigrants in the same neighbourhood as a Christian persecution of Muslims. "It puts our policemen and of course Kenyans who are of Christian descent at a very dangerous position because now you are being looked at as a person who is likely to mistreat Muslims," he says. "And the problem is that, if that happens, let's say in Nairobi, let's say in Umoja and that stays in Umoja (an east Nairobi neighbourhood), then it is okay, because you can handle it. But if it happens so and it is posted on social media and we don't have regulations and rules and laws on how to regulate that, then what happens is that it is going to be copied in Eastleigh, it is going to be copied in other areas, and that can easily turn something small into a very dangerous thing."

Ogoda highlights a particularly upsetting situation in a country that, like most in the global South, has had to go through faster sociocultural change and political integration than others. "The other aspect of it which is annoying and negative for the society, parents don't know children, children don't know parents. They don't. They sit together at home. They are eating at table. They are sitting in the living room. Each of them is busy. They are in a group but they are individually alone. And therefore the family is losing the influence on the values to be instilled in those 
formative years. Even as a teenager I used to insist on knowing who the friends of my children are. You are free to bring them home. We are going to have tea together and things like that. That doesn't pertain anymore. I don't know who they are twittering with, whatsapping with, or facebooking with. I have no idea."

She says that parents now face a "technical lock-out" from their children's lives.

Abdi shares Ogoda's concerns. He says: “We have a generation of young people who do not read the papers or listen to the radio. They go to (blogger and activist Boniface) Mwangi's blog and they have a highly coloured perspective on things."

Abdalla Seif Dzungu, who is an online reporter for the BBC based in Nairobi, says that the organisation's mobile-device driven news platforms receive most hits for "light stories". This he feels, as do others, renders social media a somewhat lacking site for serious policy debate. He says: "I have realised that when you post news stories, you don't get many audiences. I mean: you don't get many people as compared to online stories about-I mean as compared to light stories... Yes, (light stories get more attention as) compared to hard news."

This, too, is the observation of Wambui Kiai, director of the School of Journalism at the University of Nairobi, Kenya's oldest and pre-eminent graduate school of journalism. "Is social media just about light issues and entertainment?" she asks. Kiai, whose research interests include development, health and environmental communications, says that social media has potential for much more than this. She 
says the potential is there but not enough actors are taking advantage of the media. As a mother and an educator, she also expresses the same fears as Ogoda does. She says: "The face-to-face contact is quite important in many respects... You have to ask yourself the whole idea of interaction. We are losing the interactivity. Even when we sit together. And I see it now - and I see it! After the greetings—and there is a place where we sit in the club (the University of Nairobi Senior Common Room, which is reserved for faculty)—and after some time everybody is on (social media). And half an hour goes! And so you are already not there as a person. Where are some of the boundaries that are important? The tastefulness, the etiquette, you know, the ethics?... Where are the national values, the national ethos?"

Ogoda says that she has had to punish some of her students for appalling grammar, which she blames partly on the language used in social media. She says that social media is normalising linguistic mediocrity, leading young people to believe that the highly abbreviated and variable jargon of Kenya's social media, complete with its casual attitude to punctuation, is universally acceptable. She says: "It is not just social manners. Wait until as a teacher I assign a term paper! It is not the Englishking's or queen's English, American or British. It is not English by any measure, by any standard, by any grammar rules-it is not English what they write!"

Abdi blames this on the nature of social media. "Newspapers and the like have editorial boards and other filters," he says. "Legacy media is mediated. Not so social media. You have no gatekeepers. The language of these unmediated communicators 
is also bad in linguistics. It is bad for young people who are looking to these writers for cues."

Gichuki feels that even at its worst, social media is a boon for the country's nationbuilding project. He says that social media has provided a democratising alternative to legacy media, which he adds was subject to many restrictions. He and others described to me some of the reasons why mainstream media remained anything but free in the country. "There is a perceived notion that Kenya's formal media is free," he says. "But I disagree that Kenya's media is free for a plurality of reasons: state advertising, ownership, downright corruption, and bribery."

Regarding government advertising, he says: "The government spends-this government spends massively on press-it can choose which media companies swim or die because they can choose to hold back advertising revenues from (them). And you know you have a private sector that spends, but government spends massively. The regulations are only that government when it advertises must pick three national dailies. Now, the Star is a national daily, the Nation is a national daily, the Standard is a national daily, People is a national daily, the Citizen Weekly is a national daily if you like. So the government has a lot of power to shape editorial policy purely by throwing money at media houses. It says, 'Do you want this money? Then you cannot put out these kinds of headlines."' 
With regards media ownership, he notes that all of the country's main media houses are directly controlled by key political figures or people in private business with them: the Standard Media Group by former President Moi, MediaMax by Kenyatta, the Citizen Media Group by key Odinga ally SK Macharia, and the Nation Media Group by Kenyatta business partner the Aga Khan. "You realise that... editorial policy... can(not) stray very far from the will of the owners of these companies," he says. "The KBC is state-controlled and therefore likely to kowtow to the powers that be... The Aga Khan... is business partners with the Kenyattas... So if they are doing business at that level, then the Aga Khan would have an implicit interest in the status quo-not in disrupting the status quo."

In addition, Gichuki says, mainstream media continues to suffer from ethnic bias. This has been compounded by corruption, with journalists reportedly on the take. Social media has become a real alternative to legacy media as a result. "There is no gatekeeper between me and my Twitter account," he says. "I can report things as I see them. I can upload those pictures as I see them... So in a certain sense social media has democratised newsgathering and the relay of news."

Gichuki says that social media has opened up the country's public institutions to irreversible change. He gives the example of energy monopoly Kenya Power that, together with sister company KenGen, generates and distributes power across the country. He says Kenya Power's presence on social media has opened them up to direct feedback from their customers, obliging them to respond and be seen to be 
responding. "It is a giant—a dinosaur if you like," he says. "The bite pre-social media happening on T-rex's tail may not be perceptible to T-rex's head, because it is a giant... What social media does is to remove the gatekeepers in those institutions who would channel what information they perceive to be favourable or in their favour to their bosses. And what it does is that as long as the fellow at the top has a Twitter account, in real time, they have a very real sense whether they are doing well or not." He says this development has been observed in other institutions including the judiciary, the national police force and the presidency. Social media, he says, has become a "barometer" that these institutions can use to gauge public opinion.

Gichuki says that social media is taking on a legacy of authoritarianism that has bequeathed to the country public institutions so used to withholding information that they can hardly communicate among themselves. He observes that the capacity of social media to transform the institutions of public life in Kenya does not lie just in the freedom of expression that they accord to the common people, but also in the impact that expressing themselves has on the institutions. "The more an institution of power communicates, the more it changes itself," He says. "There are things it can't do and get away with and remain credible, especially as an institution that engages people... Social media will have an incredible transformative effect on our institutions because information flow always transforms institutions." 
Kamau agrees but warns that this process may take a little while yet. "The promise and potential is there," he says. "Only that some people-I would say scholars, certain journalists and political players-have placed too much of a burden of expectation on social media and maybe technology for democratisation. So the potential is there, the promise is there, but it is not to the level that some people have pushed it... Give it a few years. One, two, three years." 


\section{CHAPTER 6: CONCLUSION}

Could the growing influence of social media on the way that new ideas are marketed in Kenya suggest a more influential role for the digital citizen in the shaping of public institutions in democratising countries? The answer is yes.

The concept of the digital citizen-loosely defined, an individual with access to digital communication who uses it to participate in public life-aptly fits this political constituency in Kenya. The chattering classes have gone online and snowballed into an unstoppable force that reaches into voiceless sections of the population that more often than not did not care or could not hope to be involved in the rough-and-tumble of politics previously. Most significant of the latter group are the youth, the country's largest demographic.

It became clear to me that the digital citizen was also likely to become the opinion maker of many. As Franceschi notes, "there are people in Kenya who have half-amillion, 600,000 followers. Well, I mean those are twice the number of newspapers the Nation (the country's largest daily) prints. So anything you say will reach everywhere, at least the people who have access to Internet. And they are mostly the younger people." Coupled with the peculiar Kenyan tradition of urban folk often influencing their rural cousins, the power of Kenya's digital citizenry begins to become clearer. As digital citizenry expands into the less-prosperous parts of the urban centres and the largely unconnected rural areas (digitally speaking, that is), it 
will become the norm rather than the exception within the next decade that Kenyans are digital citizens.

The disproportionate power of the digital citizen does raise serious concerns about the manner in which information percolates from the top to the bottom. As we have seen, a lot of hearsay passes for fact. It also became clear that a lot of this information is deliberately spun to create certain perceptions about particular political personalities and their agendas. The extent of it is such that the digital citizen has the power to disenfranchise his digitally unconnected cousins by substituting self-interested political opinion for fact.

There are other clear concerns, such as those surrounding hate speech. Policing challenges, including political bias and an insufficient legal framework, add to this particular problem. But the advantages seem to outweigh the disadvantages. Kenyans now have greater say on what is going on in public life. Public figures are being called to account in real time. The relative loss of the freedom of speech that has afflicted legacy media since Kenyatta took power has been compensated to a good extent by the expansion of social media. The institutional behemoths of Kenyan public life are being forced to shift and turn and change. That social media and the new breed of citizen it has spawned needs a lot of offline help to make Kenya a more united and democratic society is not in doubt. However, there is no doubt, either, that the politicians and the bureaucrats now cannot easily cheat citizens out of their fair say on things. 


\section{LIST OF PRIMARY SOURCES}

so Academia

P OGODA (PhD): lecturer in Political Science, University of Nairobi, Nairobi, Kenya.

Sam KAMAU (PhD): lecturer, the School of Journalism, University of Nairobi, Nairobi, Kenya. Kamau is also the Examination Officer and Website Champion for the school.

Luis FRANCESCHI: founding Dean and Lecturer in International and Constitutional Law, the Strathmore Law School, Strathmore University, Nairobi, Kenya.

Wambui KIAI: Director, the School of Journalism, University of Nairobi. Kiai's interests include Development Communications, Health Communications, and Environmental Communications.

Douglas GICHUKI: Reader in Intellectual Property and Information Technology (IPIT) Law, the Strathmore School of Law, Strathmore University, Nairobi, Kenya; Advocate of the High Court of Kenya; Lead, IPIT Law, Gajama and Muma Advocates.

\section{so ICT Professional}

Mukeli MATEI: Google Ambassador (2014/2015) for Kenya; Social and Digital Media Coordinator, the Strathmore Law School, Strathmore University, Nairobi, Kenya; Student on the Master in Mobile Telecommunications and Innovation programme at the Safaricom Academy (iLab Africa), Strathmore University, Nairobi, Kenya. 


\section{\&s Journalists/Media Commentators}

Simon OCHOLA: Senior Reporter, the Kenya Broadcasting Corporation (BBC), Nairobi, Kenya. Ochola is both a political reporter on the public service broadcaster and an editor with oversight over several reporters.

Abdualla Seif DZUNGU: Online Reporter and Multimedia Journalist with the British Broadcasting Corporation (BBC), Nairobi, Kenya.

Rashid ABDI (PhD): Independent Consultant and Contributing Editor with the Nation Media Group (the sub-region's largest), Nairobi, Kenya. Abdi, a former BBC editor, specialises on sub-regional (Horn of Africa) and international affairs. He has also worked for the International Crisis Group (ICG). He has since returned to the ICG.

Mathias MUINDI: Media Analyst and Editor, BBC Monitoring, Nairobi, Kenya. Muindi has followed and analysed the media in Kenya and in Africa for the BBC for some 15 years.

$>$ Zainab DEEN: Senior Broadcast Journalist Online and Online Editor, BBC, Nairobi, Kenya. Deen has since moved to China Central Television Africa (CCTV Africa) to serve in the same capacity.

\section{\&s Development Experts}

$>$ Olga MUTORO: Programme Officer and Acting Programme Manager for Policy and Governance, Peacenet Kenya.

sos Diplomatic Media Relations and Communications Officers 
Karina GROSHEVA: Private Sector and Foundations Team, Bureau for Policy and Programme Support, United Nations Development Programme, Istanbul, Turkey.

- Kawkab ALTHAIBANI: Private Sector and Foundations Team, Bureau for Policy and Programme Support, United Nations Development Programme, Istanbul, Turkey. 


\section{BIBLIOGRAPHY}

African Studies Center, Michigan State University. "Module 10: Activity 2: Explore Types of Government in Pre-Colonial Africa." In Curriculum Entitled "Exploring Africa, Student's Edition." Accessed on 4 November 2013. http://exploringafrica.matrix.msu.edu/students/curriculum/m10/activity2.php

Alence, Rod. "Democracy and Development in Africa." The Journal of the International Institute. Volume 16, Issue 2, Spring 2009. Ann Arbour: Michigan Publishing. Accessed on 4 November 2013. http://quod.lib.umich.edu/j/jii/4750978.0016.202/--democracy-and-developmentin-africa?rgn=main;view=fulltext

Anderson, Benedict. Imagined Communities: Reflections on the Origin and Spread of Nationalism (Revised Edition). London and New York: Verso, 1991.

Anderson, David. The Cold War in Africa: A History (2006 - 2012). London: Faber and Faber, 2012. Prolepsis and summary published by the African Studies Centre, the University of Oxford accessed on 5 November 2013. http://www.africanstudies.ox.ac.uk/cold-war-africa-history-2006-2012

"Are the International Media Getting Africa Right?" BBC Africa Debate. The British Broadcasting Corporation. BBC News, Nairobi. Undated. Radio. Accessed on 5 November 2013. 
http://www.bbc.co.uk/iplayer/episode/p01fm6kh/BBC Africa Debate Are the Int ernational Media Getting Africa Right/

Atagana, Mich. "15 Key Trends Shaping Kenya’s Social and Digital Media Landscape.” Memeburn website, 20 March 2015. Accessed on 17 September 2015. http://memeburn.com/2014/03/15-key-trends-shaping-kenyas-social-and-digitalmedia-landscape/

Battera, Federico. "Ethnicity and Degree of Partisan Attachment in Kenyan Politics." Journal of Asian and African Studies (February 2013), 48 (1), pg. 114-125

Curran, James. "The Future of Journalism." Media and Democracy. New York: Routledge, 2011. 111-20.

Degu, W.A. "The State, the Crisis of State Institutions and Refugee Migration in the Horn of Africa: the Cases of Ethiopia, Sudan and Somalia (Online File Name: Political Development in the Pre-colonial Horn of Africa." File ID: 66264. Amsterdam: UvADARE, 2002. Accessed on 5 November 2013.

http://dare.uva.nl/document/66264

Deloitte. "Mobile telephony and taxation in Kenya." GSMA website, 2011. Accessed on 17 September 2015. 
http://www.gsma.com/publicpolicy/wp-

content/uploads/2012/03/mobiletelephoneandtaxationinkenya.pdf

Faul, Michelle. "West condemns Mugabe, ignores other Africa despots." USA Today website, 4 July 2008. Accessed on 5 November 2013.

http://usatoday30.usatoday.com/news/world/2008-07-04-2714701252 x.htm

Gasher, Mike. "The View from Here: A News-Flow Study of the on-Line

Editions of Canada's National Newspapers." Journalism Studies 8:2

(2007): 299-319.

Gennaioli, Nicola and Ilia Rainer. "Pre-Colonial Centralization and Institutional Quality in Africa." Barcelona: Centre de Recerca en Economia Internacional, October 2005. Accessed on 5 November 2013.

http://www.crei.eu/people/gennaioli/precolonial.pdf

Gicobi, Maryanne. "Free laptops tender cancelled." Daily Nation newspaper website 17 October 2013. Accessed on 6 November 2013.

http://www.nation.co.ke/news/Free-laptops-tender-cancelled/-/1056/2037438//152bkq8z/-/index.html

Hamman, Sophie and William Brown. "In from the margins? The Changing Place of Africa in International Relations." Chatham House website, 2013. Accessed on 6 November 2013. 
http://www.chathamhouse.org/sites/default/files/public/International\%20Affairs /2013/89 1/89 1HarmanBrown.pdf

Hammer, James. "In the Kenyan Cauldron." The New York Review of Books website. May 29, 2013 Issue. Accessed on Monday 4 October 2013.

http://www.nybooks.com/articles/archives/2013/may/09/kenyancauldron/?page $=1$.

Hellmueller, Lea, T.P. Vos and Mark A. Poepsel. "Shifting Journalistic Capital? Transparency and Objectivity in the $21^{\text {st }}$ Century." Journalism Studies 14:3 (2013): $287-304$.

Hirsch, Afua and David Smith. "Obama faces protests and boycotts on Africa tour." Dawn.com website, 26 June 2013. Accessed on 6 November 2013. http://dawn.com/news/1020831/obama-faces-protests-and-boycotts-on-africa$\underline{\text { tour }}$

Houreld, Katharine. "Rules of engagement move into the $21^{\text {st }}$ century." Mail and Guardian website, 12 December 2011. Accessed on 16 August 2015. http://mg.co.za/article/2011-12-12-rules-of-engagement-move-into-the-21stcentury 
International Monetary Fund. “World Economic Outlook Update.” January 2015. Accessed on 11 August 2015. http://www.imf.org/external/pubs/ft/weo/2015/update/01/

Jacinto, Leela. "Kenya blasts UK—with a little help from British PR firm." France 24 website, 8 March 2013. Accessed on 5 March 2013. http://www.france24.com/en/20130307-kenyatta-blasts-uk-with-little-helpbritish-pr-firm

Jacinto, Leela. "Kenya vote count under way in wake of huge turnout." France 24 website, 6 March 2013. Accessed on 5 March 2013. http://www.france24.com/en/20130305-kenyatta-takes-early-lead-kenya-votecount-underway

Kabweza, LSM. “\#SomebodyTellCNN Twitter backlash in Kenya forces CNN to apologize." Techzim website, 12 March 2012. Accessed on 6 November 2013. http://www.techzim.co.zw/2012/03/someonetellcnn-twitter-backlash-in-kenyaforces-cnn-to-apologise/

Kagwanja, Peter. "Kenyatta summit speech tipping point in Africa-West relations." Zimbabwe Independent newspaper website, 18 October 2013. Accessed on 6 November 2013. http://www.theindependent.co.zw/2013/10/18/kenyattasummit-speech-tipping-point-africa-west-relations/ 
Kaigwa, Mark W. "Kenya at 50: how social media has increased the rate of change." The Guardian website, 13 December 2013. Accessed on 17 September 2015. http://www.theguardian.com/global-development-professionalsnetwork/2013/dec/13/kenya-social-media-mark-kaigwa

Kenya's Ministry of Devolution and Planning. "Youth and Women Fund ready for launch." Ministry of Devolution and Planning website, 2013. Accessed on 6 November 2013. http://www.planning.go.ke/index.php?option=com content\&view=article\&id=505: youth-and-women-fund-ready-for-launch\&catid=1:latest-news\&Itemid=53

Khadiagala, Gilbert M. "Political movements and coalition politics in Kenya: entrenching ethnicity." South African Journal of International Affairs (April 2010), 17 (1) pg. 65-84.

Khamadi, Shitemi. “Social media, blogging use define Kenya's Internet freedom concerns." Kenya Monitor website. Accessed on 17 September 2015. http://www.monitor.co.ke/2015/05/18/social-media-use-defines-kenyas-internetfreedom-concerns/

Kolesnikov, Ivan. "World GDP ranking 2015: data and charts." knoema.com Accessed on 11 August 2015. 
http://knoema.com/nwnfkne/world-gdp-ranking-2015-data-and-charts

Konrad Adenauer Foundation. "Kriegler and Waki Reports: Summarised Version: Revised Edition 2009." Nairobi: the Konrad Adenauer Foundation. Accessed on 5 November 2013. http://www.kas.de/wf/doc/kas 16094-1522-2-30.pdf

Lees-Marshment, Jennifer. "Welcome to Political Marketing: Training to be delivered for the Graduate Programme in Political Management, Carleton University, Ottawa, Canada, October 2013."

Lynch, Gabrielle. "Moi: the making of an African 'Big Man'”. Journal of Eastern African Studies (March 2008), 2 (1), pg. 18-43

Manica, Luca and Michele Vescovi. "Mobile Telephony in Kenya: Is it Making Life Better?" Accessed on 17 September 2015. http://m.it46.se/projects/UNITN ict4sd/assignments/ICT4SD manica vescovi.pdf

McKenna, Amy. “Uhuru Kenyatta.” Encyclopaedia Britannica website. Accessed on 5 November 2013. http://www.britannica.com/EBchecked/topic/937079/UhuruKenyatta

Moore, Charles. "How the well-meaning West aids the despots: Charles Moore reviews 10 Weeks in Africa by JM Shaw." The Telegraph newspaper website, 1 
October 2012. Accessed on 5 November 2013.

http://www.telegraph.co.uk/culture/9578245/How-the-well-meaning-West-aidsthe-despots.html

Mosuku, Geoffrey. "Kikuyu, Kalenjin dominate civil service jobs." The Star newspaper website, 7 April 2011. Accessed on 6 November 2013. http://www.the$\underline{\text { star.co.ke/news/article-67270/kikuyu-kalenjin-dominate-civil-service-jobs }}$

Mugera, Solomon. “Uhuru Kenyatta: indicted president.” BBC website, 9 March 2013. Accessed on 5 November 2013. http://www.bbc.co.uk/news/world-africa$\underline{21544245}$

Murumba, Stellar. "Kenya suspends CNN deal over terrorism slur". Business Daily Africa website, 7 August 2015. Accessed on 13 August 2015.

http://www.businessdailyafrica.com/Kenya-suspends-CNN-deal-over-terrorismslur/-/539546/2822870/-/qliv68/-/index.html

Nation Reporter. "Cord likely to change tack on International Criminal Court." Daily Nation website, 28 October 2013. Accessed on 7 November 2013. http://www.nation.co.ke/news/politics/Raila-party-may-take--new-stance-on-ICC-/-/1064/2050890/-/p59fat/-/index.html 
Nyabuga, George and Nancy Booker. "Mapping Digital Media: Kenya." Open Society Foundations website, March 2013. Accessed on 17 September 2015. https://www.opensocietyfoundations.org/reports/mapping-digital-media-kenya Odinga, Ajuma Oginga. Not Yet Uhuru. New York: Hill and Wang, 1967.

Oduor, Augustine. "Jubilee's Standard One laptops projects faces setback (as published)." Standard Digital website, 18 October 2013. Accessed on 6 November 2013. http://www.standardmedia.co.ke/?articleID=2000095760\&story title=Kenya:\%20 Standard\%200ne\%20laptops\%20project $\% 20$ faces\%20setback

Okwembah, David. "Raila Odinga: third time lucky in Kenya?" BBC website, 1 March 2013. Accessed on 5 November 2013. http://www.bbc.co.uk/news/world-africa$\underline{21587054}$

Pew Research Center Global Attitudes and Trends Survey Report. “Emerging Nations Embrace Internet, Mobile Technology: Cell Phones Nearly Ubiquitous in Many Countries." 13 February 2014. Accessed on 11 August 2015. http://www.pewglobal.org/2014/02/13/emerging-nations-embrace-internetmobile-technology/ 
Phombeah, Gray. “Moi's legacy to Kenya." BBC website, 5 August 2002. Accessed on 11 August 2015. http://news.bbc.co.uk/2/hi/africa/2161868.stm

Reid, Alastair. "AfricaAt50: How technology is changing journalism in Kenya." Ubuntu Platform website, 31 May 2013. Accessed on 17 September 2015. http://ayoubmzee.blogspot.ca/2013/07/dr-congo-deploys-on-m23-frontiers.html Rono, Joseph Kipkemboi. "The Impact of the Structural Adjustment Programmes on Kenyan Society." Journal of Social Development in Africa, Vol 17 No. 1. January 2002. Pp. 81-98. Grahamstown. (Online version published by Michigan State University Library Archives, East Lansing.) Accessed on 4 November 2013. http://archive.lib.msu.edu/DMC/African\%20Journals/pdfs/social\%20development /vol17no1/jsda017001007.pdf

Singer, Ron. "How free is the free press in Kenya?" openDemocracy website, 19 August 2011. Accessed on 13 August 2015. https://www.opendemocracy.net/ron-singer/how-free-is-free-press-in-kenya

Spivak, Gayatri Chakravorty. "Can the Subaltern Speak?" Marxism and the Interpretation of Culture (1988): 271-313. 
The International Criminal Court Kenya Monitor. "The Accused." The Open Society Justice Initiative's icckenya.org website. Accessed on 5 November 2013. http://www.icckenya.org/background/the-accused/

The Truth, Justice and Reconciliation Commission of Kenya. "The Final Report of the the Truth, Justice and Reconciliation Commission of Kenya." Submitted to the President on 2 May 2013. Nairobi: the Truth, Justice and Reconciliation Commission of Kenya. Accessed on 5 November 2013. http://www.tjrckenya.org/index.php?option=com content\&view=article\&id=573\&I $\underline{\text { temid }=238}$

The Truth, Justice and Reconciliation Commission of Kenya. "Supplementary Report of the Truth, Justice and Reconciliation Commission. " Submitted to the President of Kenya on 2 May 2013. Nairobi: the Truth, Justice and Reconciliation Commission of Kenya. Accessed on 5 November 2013. http://www.tjrckenya.org/images/documents/TJRC-supplementary-report.pdf Unattributed article. "History of Media in Kenya Media Essay." UK Essays website. Accessed on 17 September 2015. http://www.ukessays.com/essays/media/history-of-media-in-kenya-mediaessay.php 
Unattributed article. "Kenya African National Union (KANU)." Encyclopaedia

Britannica website. Accessed on 5 November 2013.

http://www.britannica.com/EBchecked/topic/315155/Kenya-African-National-

Union-KANU

Unattributed article. "Kenya demands CNN apology over 'hotbed of terror' slur". BBC News Online website, 23 July 2015. Accessed on 15 August 2015.

http://www.bbc.com/news/world-africa-33642158

Unattributed article. "Kenya Press, Media, TV, Radio, Newspapers". Press Reference website. Accessed on 11 Agusut 2015.

http://www.pressreference.com/Gu-Ku/Kenya.html

Unattributed article. "Media in Kenya”. Softkenya website. Accessed on 17

September 2015. http://softkenya.com/media/

Unattributed image. Caption: "News in Pictures: show of unity: Raila Odinga holds hand (as published) with Uhuru Kenyatta as they do carpet walk in Nyando." Kenya Today website, undated. Accessed on 6 November 2013. http://www.kenyatoday.com/pictures/show-of-unity-raila-odinga-uhuru-kenya-atta-in-nyando 
Unattributed report, datelined Nairobi. "A chip off the old Kikuyu block." 16 March 2013. The Economist website. Accessed on Monday 4 November 2013. London: The Economist Group, 16 March 2014.

http://www.economist.com/news/middle-east-and-africa/21573596-uhurukenyatta-must-convince-kenyans-he-his-own-man-chip-old

Unattributed report. “Dividing Kenya along ethnic lines.” BBC website, 3 September 2001. Accessed on 6 November 2013.

http://news.bbc.co.uk/2/hi/africa/1523421.stm

Unattributed report. "Robert Ouko 'killed in Kenya State House."” BBC website, 9 December 2010. Accessed on 5 November 2013.

http://www.bbc.co.uk/news/world-africa-11962534

Unattributed report. "The Story of Africa." BBC website. Accessed on 5 November 2013.

http://www.bbc.co.uk/worldservice/africa/features/storyofafrica/12chapter8.sht $\underline{\mathrm{ml}}$

US State Department. “A Brief History of Kenya." Published by AfricanHistory.About.com. Accessed on 4 November 2013. http://africanhistory.about.com/od/kenya/p/KenyaHist.htm 
Verini, James. "The Kenyatta Affair: what Kenya and its allies can learn from Austria's Nazi legacy." Foreign Policy magazine, March 20, 2013. Washington, DC: The Slate Group. Accessed on Monday 4 November 2013.

http://www.foreignpolicy.com/articles/2013/03/20/the kenyatta affair kenya ele ction

Warungu, Joseph. "Letter from Africa: Kenya passes electoral test - but what next?" BBC website, 12 March 2013. Accessed on 6 March 2014.

http://www.bbc.co.uk/news/world-africa-21745501

Warungu, Joseph. "Letter from Africa: Kenya a country of firsts." BBC website, 19 November 2013. Accessed on 6 November 2014.

http://www.bbc.co.uk/news/world-africa-24134014

Willett, Megan. "Here is what the world would look like if countries were as big as their population sizes." Business Insider website, 30 January 2015. Accessed on 11 August 2015.

http://www.businessinsider.com/world-map-based-on-population-size-2015-1

World Economic Forum. “Global Information Technology Report 2015.” 15 April 2015. Accessed on 11 August 2015.

http://reports.weforum.org/global-information-technology-report-2015/ 
Zelizer, Barbie. "Journalists as Interpretive Communities." Critical Studies in Mass Communications 10:3 (1993): 219-37. 